\title{
INVESTMENT COURT SYSTEM UNDER CETA AND THE AUTONOMY OF EU LAW
}

\author{
Igor Materljan, MSc, Legal Officer \\ European Commission, DG EUROSTAT \\ 5, rue Alphonse Weicker - bâtim. Joseph Bech, 2721 Luxembourg \\ igor.materljan@gmail.com
}

\begin{abstract}
The paper focuses on the Comprehensive Economic and Trade Agreement between Canada and the European Union and its Member States, signed in Brussels on 30 October 2016 (CETA), on the investor-state dispute settlement mechanism contained therein and its compatibility with the EU legal system. It analyses the question of autonomy of the EU legal system and the difficult relationship between the Court of Justice of the European Union (CJEU) and other international jurisdictions. It identifies the compatibility conditions of different dispute settlement mechanisms developed in the CJEU's earlier case law; e.g. the allocation of powers fixed by the treaties founding the EU must not be affected, the primacy of EU law and its direct effect must be assured, the mechanism must preserve the role of national courts and tribunals to ensure the full application of EU law in all Member States, the CJEU's exclusive jurisdiction to give binding interpretations of the EU law must be assured and any action by the international tribunal must not have the effect of binding the EU and its institutions, in the exercise of their internal powers. In its opinion 1/17, the CJEU softened its approach. The paper examines how different the Investment Court System under CETA is.
\end{abstract}

Keywords: Comprehensive Economic and Trade Agreement between Canada, of the one part, and the European Union and its Member States, of the other part (CETA), Investor-State Dispute Settlement, Compatibility with EU law, Requirement to respect the autonomy of the EU legal order

\footnotetext{
* The content of this paper does not reflect the official policy or position of the European Union. The views expressed in the paper are those of the author and have not been endorsed by any service of the European Commission. Responsibility for the information and views expressed therein lies entirely with the author. The author would like to thank the anonymous reviewers for their constructive and insightful comments and suggestions
} 


\section{INTRODUCTION}

This paper focuses on the Comprehensive Economic and Trade Agreement between Canada and the European Union and its Member States, signed in Brussels on 30 October 2016 (CETA). ${ }^{1}$ CETA is a free trade agreement that contains not only provisions on the reduction of customs duties and of non-tariff barriers to trade in goods and services, but also rules relating, among others, to investment, public procurement, competition, intellectual property protection and sustainable development. The paper delves into investor-state dispute settlement mechanism contained therein ${ }^{2}$ and its compatibility with the EU legal system. In particular, it discusses the recent opinion of the Court of Justice of the European Union (CJEU) on the compatibility of CETA with EU law. ${ }^{3}$

It is difficult to write a paper on investment during the coronavirus outbreak. The containment measures linked to the COVID-19 pandemic have far-reaching social and economic repercussions. As a direct consequence of this crisis, many enterprises will be forced to close or to revise their earnings estimates. Even though there is no precise and reliable data and analysis at the time of writing, in general it is considered that the outbreak will cause a dramatic drop in foreign direct investment flows. The estimations of the fall range from 30 to 40 percent during 20202021. ${ }^{4}$ Not all sectors will be hit at the same rate and the negative consequences of the crisis will depend on policy responses, which vary from country to country. Having said that, I do not think that the coronavirus crisis will make foreign investment disappear. On the contrary, my impression is that it will strengthen free trade on a global scale, forcing developing countries to provide more protection to foreign investors. ${ }^{5}$

1 Comprehensive Economic and Trade Agreement (CETA) of 30 October 2016 between the European Union and its Member States, of the one part, and Canada, of the other part, [2017] OJ L 11

2 Chapter Eight (Investment), Section F (Resolution of investment disputes between investors and states) of the CETA

3 CJEU, Opinion 1/17 EU-Canada CET Agreement [2019] EU:C:2019:341, hereafter: Opinion 1/17

4 United Nations Conferences on Trade and Development, The IPA Observer: Investment Promotion agencies striving to overcome the COVID-19 challenge, Special issue 8, April 2020, available at: [https:// unctad.org/en/PublicationsLibrary/diaepcbinf2020d2_en.pdf?user=46], accessed 20. June 2020

5 To cope with the crises, the most common reaction of governments was to tighten the borders and bolster domestic production of strategic goods; this inevitably affected the free trade of a number of products. On the other hand, international conglomerates have their own strategies to avoid increased protectionism, especially those that heavily invested in developing economies. It is hard to expect that these conglomerates would build plants in their home countries and forgo their profit maximizing strategies of producing in growing economies that offer cheap wages and resources. On a political scale, the COVID-19 pandemic will be used as an opportunity to engage in investing in new technologies that will shape the global economy in the coming years. This investment will serve as a counterbalance to the debt governments are accruing to fight the crisis. The current economic downturn has placed 
The official position of the developing countries promoting free trade is that there is a strong relationship between foreign investment and economic growth and that foreign direct investments are critical for developed and emerging market countries. ${ }^{6}$ However, there is no real evidence supporting that conclusion. ${ }^{7}$ The relationship between foreign investment and economic growth can be seen the other way round, i.e. that foreign investors invest in countries which already have economic growth. ${ }^{8}$ Multinational enterprises often use sophisticated promotion techniques, as well as large grants and subsidies, to target valuable investments in both developed and developing nations.

Capital flows ${ }^{10}$, including foreign direct investments, have increased significantly in recent decades. As a cause and consequence of globalization and free trade, foreign direct investment flows reached almost USD 1640 billion in 2015. ${ }^{11}$ There are several international organisations that keep track of foreign direct investment

smaller economic operators situated mostly in developing countries and using outdated technology at risk of collapse. Only operators having access to adequate resources will withstand the economic slump. This access to resources can be provided by the advanced economies that will lead the global economic response to the crisis. The developing countries in financing needs will be forced to agree to participate in new free-trade agreements, establishing standards of free trade and investment practices which will strengthen even more the position of the investor. See in this regard Cimmino J. et al., A Global Strategy for Shaping the Post-COVID-19 World, The Atlantic Council of the United States, 2020, available at: [https://www.atlanticcouncil.org/wp-content/uploads/2020/07/AC-A-Global-Strategyfor-Shaping-the-Post-COVID-19-World.pdf], accessed 20. June 2020

6 European Commission, Communication to the European Parliament, the Council, the European Economic and Social Committee and the Committee of the Regions, Towards a comprehensive European international investment policy, COM/2010/0343 final, p. 3, available at: [https://eur-lex.europa.eu/LexUriServ/LexUriServ.do?uri=COM:2010:0343:FIN:EN:PDF], accessed 20. June 2020

7 Foreign ownership of companies in strategically important industries could lower the comparative advantage of the nation. Loungani, P., Razin, A., How Beneficial Is Foreign Direct Investment for Developing Countries?, Finance \& Development, vol. 38, no. 2, 2001, available at: [https://www.imf.org/ external/pubs/ft/fandd/2001/06/loungani.htm], accessed 20. June 2020

8 For an interesting and provocative view on free trade, see Chang, H.J., Bad Samaritans: The Myth of Free Trade and the Secret History of Capitalism, Bloomsbury Press, New York, 2008

9 United Nations Conference on Trade and Development, World Investment Report 2003, FDI Policies for Development: National and International Perspectives, United Nations, New York and Geneva, 2003, p. 86, available at: [https://unctad.org/en/docs/wir2003light_en.pdf], accessed 20. June 2020

10 Capital flows can take the form of grants, debt and equity investment. The latter can contain control by the investor over the activity, which is a foreign direct investment, or can be without control, which is portfolio equity investment. Williamson, J., Curbing the Boom-Bust Cycle: Stabilizing Capital Flows to Emerging Markets: Policy Analyses in International Economics, Institute of International Economics, Washington, 2005, p. 38

11 Organisation for Economic Co-operation and Development, FDI flows, available at: [https://data. oecd.org/fdi/fdi-flows.htm], accessed 20. June 2020 
statistics, e.g the United Nations Conference on Trade and Development ${ }^{12}$, the Organization for Economic Cooperation and Development ${ }^{13}$ and the International Monetary Fund ${ }^{14}$.

The main ways to attract foreign direct investment are: 1) reducing obstacles by removing restrictions on admission and establishment, as well as on the operations of foreign affiliates; 2) improving standards of treatment of foreign investors by granting them non-discriminatory treatment, vis-à-vis domestic or other foreign investors; 3) protecting foreign investors through provisions on compensation in the event of nationalization or expropriation, on dispute settlement, and on guarantees on the transfer of funds; and 4) promoting foreign direct investment inflows through measures that enhance a country's image, provide information on investment opportunities, offer location incentives, facilitate foreign direct investments by institutional and administrative improvements and render post-investment services. ${ }^{15}$ International investment agreements, concluded at bilateral, regional and multilateral levels, are a powerful tool for countries promoting free trade to encourage developing countries to open up their markets in order to obtain more of that investment. They tend to make the regulatory framework more transparent, stable, predictable and secure, and thus provide more security for foreign investments. ${ }^{16}$

There are two types of international investment agreements: the stand-alone investment treaties, which are referred to as bilateral investment treaties, and investment chapters in broader trade and investment agreement, such as the Energy Charter Treaty ${ }^{17}$. Both of them are subject to increasing scrutiny, debate and

12 United Nations Conference on Trade and Development, Global Investment Trends Monitor (Series), available at: [https://unctad.org/en/Pages/Publications/Global-Investment-Trends-Monitor-\%28Series\%29.aspx], accessed 20. June 2020

13 Organization for Economic Cooperation and Development, Foreign Direct Investment Statistics: Data, Analysis and Forecasts, available at: [http://www.oecd.org/investment/statistics.htm], accessed 20. June 2020

14 International Monetary Fund, available at: [http://data.imf.org/]. See also International Monetary Fund, Press Release No. 10/510, IMF Publishes First Worldwide Survey of Foreign Direct Investment Positions, 22.12.2010, available at: [https://www.imf.org/en/News/Articles/2015/09/14/01/49/pr10510], accessed 20. June 2020

15 United Nations Conference on Trade and Development, World Investment Report 2003, op. cit., 89

16 Ibidem, p. 91

17 Council and Commission Decision of 23 September 1997 on the conclusion, by the European Communities, of the Energy Charter Treaty and the Energy Charter Protocol on energy efficiency and related environmental aspects (98/181/EC, ECSC, Euratom) [1998] OJ L 69. The European Union and Euroatom are members of the Energy Charter Treaty as well as all Member States, except Italy. Italy withdrew from the Energy Charter Treaty and Protocol on Energy Efficiency and Related Environmental Aspects in 2016. See Energy Charter Secretariat, Italy, available at: [https://energycharter. org/who-we-are/members-observers/countries/italy/], accessed 20. June 2020 
reform. ${ }^{18}$ The most problematic part is the establishment of the investor-State dispute settlement mechanism. It presents a unique system for dispute settlement under international law involving individuals, and it plays a central role when it comes to the fulfilment of obligations arising from these investment treaties.

The Commission has already concluded the negotiation with Canada and of two other free trade agreements with almost identical provisions with Singapore and Vietnam. Similar agreements are being negotiated with Japan, Malaysia, Mexico, Chile, the Philippines, Australia and Indonesia; as well as autonomous investment protection agreements with China and Myanmar (previously known as Burma). The Commission has been authorized by the Council under Article 218 (5) TFEU to negotiate agreements with similar provisions with India, the USA, Morocco, Jordan, Egypt, Tunisia and Russia. ${ }^{19}$

The first part of the paper explores the state of play concerning the investment protection in intra-EU relations, including the new developments on the application of Achmea judgement ${ }^{20}$ in disputes emerging from the Energy Charter Treaty. It also explores the main characteristics of the dispute settlement mechanism proposed by the Commission.

The second part explores the question of autonomy of the EU legal system and the difficult relationship between the CJEU and other international jurisdictions. This section analyses the opinion of the CJEU. It should be, however, noted that there are two main grounds to examine the CETA's compatibility with EU law, i.e. the question of autonomy and that of non-discrimination. The latter is not included in the analysis, and it is left for later considerations.

These two sections provide adequate material for the final analysis and conclusion.

\section{STATE OF PLAY}

\subsection{Intra-EU relations}

At the European Union level, intra-EU treaties which envisage investor-state dispute mechanisms are considered not compatible with the EU law. In fact, in its

18 Organization for Economic Cooperation and Development, Business and Finance Outlook 2016, Chapter 8: The impact of investment treaties on companies, shareholders and creditors, p. 229, available at: [https://www.oecd.org/daf/inv/investment-policy/BFO-2016-Ch8-Investment-Treaties.pdf], accessed 20. June 2020

19 European Commission, Negotiations and agreements, available at: [https:/ec.europa.eu/trade/policy/ countries-and-regions/negotiations-and-agreements], accessed 20. June 2020

20 CJEU, C-284/16 Slowakische Republik v Achmea BV [2018] EU:C:2018:158, hereafter: Achmea 
Achmea judgement in March 2018 the CJEU established that articles 267 and 344 of the Treaty on the Functioning of the European Union ${ }^{21}$ preclude the arbitration clause contained in bilateral investment treaties concluded between Member States. ${ }^{22}$ The reason is that such arbitration mechanisms are not compatible with the autonomy of the EU legal order.

The judgement does not affect bilateral investment treaties concluded between Member States and third countries. However, these treaties impinge on the competence of the European Union in investment matters. In this regard and for practical reasons, Regulation No 1219/2012 23 provisionally empowers Member States to maintain their treaties in force.

The European Commission tries to extend the CJEU's reasoning developed in Achmea to multilateral investment treaties which contain comparable provisions on the protection of investments. In its views, even though it has been approved by the Council and the Commission, the multilateral Energy Charter Treaty cannot be used as a basis for dispute settlement between EU investors and EU Member States. ${ }^{24}$

However, arbitral tribunals constituted under the rules of the International Centre for Settlement of Investment Disputes (ICSID) and established for intra-EU disputes on the basis of Energy Charter Treaty did not follow Commissions' arguments. On the contrary, they rejected the application of Achmea judgement, underlying that the judgement applied only to bilateral investment treaties, and not to multilateral ones like the Energy Charter Treaty. ${ }^{25}$

21 Treaty on the Functioning of the European Union, Consolidated version [2012] OJ C 326/47

22 For a detailed analysis see Materljan, I., Investment Protection and the EU Law, International Commercial Arbitration Review (Вестник международного коммерческого арбитража), Vol. 17, No. 2/2018, pp. 114-143, available at: [http://arbitrationreview.ru/wp-content/uploads/2019/04/!vestnik_MKA_cover_2_2018.pdf], accessed 20. June 2020

23 Regulation (EU) No 1219/2012 of the European Parliament and of the Council of 12 December 2012 establishing transitional arrangements for bilateral investment agreements between Member States and third countries, [2012] OJ L 351

24 European Commission, Fact Sheet: Commission provides guidance on protection of cross-border EU investments - Questions and Answers, 19 July 2018, available at: [http://europa.eu/rapid/press-release_ MEMO-18-4529_en.htm], accessed 20. June 2020

25 ICSID, Case No. ARB/13/31, Antin Infrastructure Services Luxembourg Sàrl and Antin Energia Termosolar BV v Kingdom of Spain; ICSID, Case No. ARB/12/12, Vattenfall $A B$ and others $v$ Federal Republic of Germany; ICSID, Case No. ARB/14/1, Masdar Solar \& Wind Cooperatief U.A. v. Kingdom of Spain; ICSID Case No.ARB/13/36, Eiser Infrastructure Limited and Energia Solar Luxembourg Sarl v. Kingdom of Spain; ICSID, Case No. ARB/14/3, Blusun S.A., Jean-Pierre Lecorcier and Michael Stein v. Italian Republic 
The same approach on arbitral tribunals was employed under the rules of the Arbitration Institute of the Stockholm Chamber of Commerce (SCC) ${ }^{26}$ In this regard, the case Novenergia $v$. Kingdom of Spain ${ }^{27}$ deserves special attention. The award ordering Spain to pay a compensation of $€ 53,3$ million for the breach of the Energy Charter Treaty is challenged before the Svea Court of Appeal. Spain argues that the arbitral tribunal exceeded its jurisdiction in hearing the case, basing its argument on Achmea judgement. The Swedish Court decided to stay any enforcement of the award, making it impossible for the investors to enforce it, while the challenge is pending. It is to be seen whether the Svea Court of Appeal will refer the case to the CJEU by way of a preliminary reference under Article 267 TFEU. ${ }^{28}$

In January 2019, Member States issued three declarations concerning the legal consequences of Achmea in relation to further intra-EU investor-state arbitrations. The first declaration is signed by the majority of Member States (22 of them). They undertook to: 1) inform arbitral tribunals in all pending arbitrations about the legal consequences of Achmea; 2) inform "the investor community" that no new intra-EU investment arbitration proceedings should be initiated; 3) request their national courts and any third country courts to set aside and/or not to enforce any intra-EU investor-state awards, due to a lack of valid consent to arbitration; 4) procure that any state entities which have brought investment arbitration claims against another Member State will withdraw those claims; and 5) terminate all intra-EU BITs by way of a plurilateral treaty or (if more expedient) bilaterally, ideally by 6 December $2019 .{ }^{29}$

Member states Finland, Luxembourg, Malta, Slovenia and Sweden signed a second declaration. These Member States recognised that the question of Achmea's applicability to the Energy Charter Treaty is being considered in the Novenergia $v$. Kingdom of Spain appeal. Thus, they will not take the actions specified in the first declaration with regard to intra-EU claims unless and until the CJEU has deter-

26 SCC, Case No. V 062/2012, Charanne B.V. and Construction Investments S.á.r.l v. Kingdom of Spain; SCC, Case No. V 2013/153, Isolux Netherlands, BV v. Kingdom of Spain

27 SCC, Case No. 063/2015, Novenergia v. Kingdom of Spain

28 Dahlquist, J., Spain challenges Novenergia arbitral award in Swedish court, relying on the Achmea judgment, 23 May 2018, available at: [https://aquiescencia.net/2018/05/23/spain-challenges-novenergia-arbitral-award-in-swedish-court-relying-on-the-achmea-judgment/], accessed 20. June 2020

29 Declaration of the Representatives of the Governments of the Member States of 15 January 2019 on the legal consequences of the Judgment of the Court of Justice in Achmea and on Investment Protection in the European Union, available at: [https://ec.europa.eu/info/sites/info/files/business_economy_euro/banking_and_finance/documents/190117-bilateral-investment-treaties_en.pdf], accessed 20. June 2020 
mined whether the Achmea principles apply equally to claims under the Energy Charter Treaty. ${ }^{30}$

Hungary issued a third declaration, expressly stating that Achmea does not apply to claims under the Energy Charter Treaty. ${ }^{31}$

It follows that, at least concerning the energy sector, an investor can bring an intra-EU claim under the Energy Charter Treaty before an arbitral tribunal, which will most likely accept its jurisdiction. The problem that can arise is how to enforce a reward delivered by an arbitration tribunal under the rules of that multilateral treaty. It is clear from the first and the second declarations that the majority of Member States will not enforce such an award. It seems that only Hungary is unlikely to contest jurisdiction in, and enforcement of, an intra-EU arbitral claim on Achmea grounds.

In these conditions, an investor can always try to enforce an award outside the European Union or to obtain protection before national courts of the sued Member State. ${ }^{32}$

On 5 May 2020, most of the Member States (apart from Austria, Finland, Sweden and Ireland) signed the Agreement for the termination of bilateral investment treaties between the Member States of the European Union. ${ }^{33}$ According to this agreement, all bilateral investment treaties listed in the annexes are thereupon terminated (including their sunset clauses that are deprived of legal effects). Consequently, arbitration clauses included in those agreements cannot serve as a basis for future litigation. It must be however noted that the discussion on the applicability of the Achmea judgement to intra-EU disputes is far from over. In this respect, two cases should be briefly examined.

30 Declaration of the Representatives of the Governments of the Member States of 16 January 2019 on enforcement of the Judgment of the Court of Justice in Achmea and on Investment Protection in the European Union, available at: [https://www.regeringen.se/48ee19/contentassets/d759689c0c804a9ea7af6b2de7320128/achmea-declaration.pdf], accessed 20. June 2020

31 Declaration of the Representative of the Governments of Hungary of 16 January 2019 on the legal consequences of the Judgment of the Court of Justice in Achmea and on Investment Protection in the European Union, available at: [http://www.kormany.hu/download/5/1b/81000/Hungarys\%20Declaration\%20on\%20Achmea.pdf], accessed 20. June 2020

32 European Commission, Press release, Capital Markets Union: Commission provides guidance on protection of cross-border EU investments, 19 July 2018, available at: [http://europa.eu/rapid/press-release_IP18-4528_en.htm?locale=en], accessed 20. June 2020

33 Agreement for the termination of bilateral investment treaties between the Member States of the European Union, available at: [https://ec.europa.eu/info/sites/info/files/business_economy_euro/banking_and_finance/documents/200505-bilateral-investment-treaties-agreement_en.pdf], accessed 20. June 2020 
In the Micula case, the ICSID ruled that Romania breached the bilateral investment treaty concluded with Sweden and awarded the investors ca. 178 millions of euros of damages. ${ }^{34}$ Considering the payment of arbitral award as illegal state $\operatorname{aid}^{35}$ the European Commission imposed on Romania not to implement the said award. ${ }^{36}$ Romania requested the annulment of the award, but the ICSID rejected the claim. ${ }^{37}$ In the meantime, the investors requested before the General Court the annulment of the Commission's decision and obtained it. The General Court upheld their application considering that EU State aid law was inapplicable in the present situation. ${ }^{38}$ The decision was appealed by the Commission before the CJEU and the case is still pending. ${ }^{39}$

The investors lodged applications for recognition and execution of the arbitral award before a number of national courts, among others in Belgium and the United Kingdom. The Brussels Court of Appeal suspended the enforcement of an arbitral award and requested a preliminary ruling from the CJEU regarding the impact of the Commission's decision on the Member States' obligation to enforce arbitral awards. ${ }^{40}$ Unlike the Belgian court, the UK Supreme Court lifted the stay on the enforcement of the award. ${ }^{41}$ When balancing the duties under EU law, especially the sincere cooperation duty, on the one hand, and the UK's international obliga-

34 ICSID Case No ARB/05/20, Ioan Micula, Viorel Micula, SC European Food SA, SC Starmill SRI, SC Multipack SRL v Romania, Final Award of 11 December 2013

35 European Commission, Press release, State aid: Commission refers Romania to Court for failure to recover illegal aid worth up to $€ 92$ million, 7 December 2018, available at: [http://europa.eu/rapid/press-release_IP-18-6723_en.htm], accessed 20. June 2020

36 Commission Decision (EU) 2015/1470 of 30 March 2015 on State aid SA.38517 (2014/C) (ex 2014/ NN) implemented by Romania - Arbitral award Micula v Romania of 11 December 2013 (notified under document C(2015) 2112), [2015] OJ L 232

37 ICSID, Case No. ARB/05/20 Annulment Proceedings, Ioan Micula, Viorel Micula and others (Respondents on Annulment) (Claimants) v. Romania (Applicant on Annulment) (Respondent), Decision on Annulment of 26 February 2016

38 General Court of the European Union, Cases T-624/15, T-694/15 and T-704/15, European Food SA and Others v European Commission [2019] ECLI:EU:T:2019:423

39 CJEU, InfoCuria, Case C-638/19 P, appeal brought on 27 August 2019 by European Commission against the judgment of the General Court (Second Chamber, Extended Composition) delivered on 18 June 2019 in Case T-624/15: European Food e.a. $v$ Commission, available at: [http://curia.europa.eu/juris/document $/$ document.jsf?text $=\&$ docid $=219134 \&$ pageIndex $=0 \&$ doclang $=E N \&$ mode $=$ req $\&$ dir $=\& o c c=-$ first\&part=1\&cid=6657449], accessed 20. June 2020

40 Cour d'appel Bruxelles, Arrêt du 12 mars 2019, 2016/AR/393 joint avec 2016/AR/394, available at: [https://jusmundi.com/en/document/decision/fr-ioan-micula-viorel-micula-and-others-v-romania-iarret-de-la-cour-dappel-de-bruxelles-tuesday-12th-march-2019], accessed 20. June 2020

41 Supreme Court of the United Kingdom, Judgement of 19 February 2020, Micula and others (Respondents/Cross-Appellants) v Romania (Appellant/Cross-Respondent), UKSC 2018/0177, [2020] UKSC 5, available at: [https://www.supremecourt.uk/cases/docs/uksc-2018-0177-judgment.pdf], accessed 20. June 2020 
tions under ICSID Convention, on the other, the UK Supreme Court decided in favour of the latter. Some commentators suggested that with this decision, it made the UK a fertile ground for the enforcement of intra-EU awards. ${ }^{42}$

The second case concerns PL Holdings S.à.r.l. v Republic of Poland. The foreign investor, PL Holdings, had acquired shares in two Polish banks, which merged making the investor the owner of $99 \%$ of the shares in the new bank. The Polish Financial Supervision Authority decided to cancel PL Holding's voting rights for its shares in the bank and forced it to sell them. The arbitral tribunal awarded the investor damages (ca. 150 million of euros) stating that Poland violated the bilateral investment treaty signed with the Belgium-Luxembourg Economic Union. ${ }^{43}$ Referring to the Achmea case, Poland challenged the award before the Swedish court stating that the arbitration clause contained in the bilateral investment treaty is contrary to EU law. However, the Swedish Court of Appeal rejected Poland's claim. ${ }^{44}$ Poland appealed and the Supreme Court ${ }^{45}$ decided to stay the proceedings and to request a preliminary ruling from the CJEU. ${ }^{46}$

It is clear that the dispute settlement clause contained in the bilateral investment treaty was invalid under EU law. CJEU considers submission of such disputes to an arbitral tribunal contrary to EU law. The Swedish Supreme Court tries to find a way to circumvent the outcome resulting from the strict application of Achmea. With its referral, it asked the CJEU whether the investor's request for arbitration could be considered as an offer to the host state to accept jurisdiction in accordance with the principles set out in Achmea in respect to the party autonomy commercial arbitration. Some commentators noted that it is not likely that the CJEU will relax the strict rule contained in Achmea. ${ }^{47}$ In any case, the story

${ }_{42}$ Croisant, G., Micula Case: The UK Supreme Court Rules That The EU Duty OfSincere Co-operation Does Not Affect The UK's International Obligations Under The ICSID Convention, Kluwer Arbitration Blog, 20 February 2020, available at: [http://arbitrationblog.kluwerarbitration.com/2020/02/20/miculacase-the-uk-supreme-court-rules-that-the-eu-duty-of-sincere-co-operation-does-not-affect-the-uksinternational-obligations-under-the-icsid-convention/], accessed 20. June 2020

43 SCC, Case No. V 2014/163, PL Holdings S.à.r.l./. Republic of Poland, Partial award of 28 June 2017

44 Svea Court of Appeal, Judgement of 22 February 2019, T 8538-17, T 12033-17, unofficial translation, available at: [https://www.italaw.com/sites/default/files/case-documents/italaw10447.pdf], accessed 20. June 2020

45 Högsta Domstolen, Republiken Polen v. PL Holdings S.Á.R.L., Begäran om förhandsavgörande den 12 december 2020, T 1569- 19, available at: [https://www.italaw.com/sites/default/files/case-documents/ italaw11099.pdf], accessed 20. June 2020

46 The case is registered under C-109/20. The translation is available here: [http://curia.europa.eu/ juris $/$ showPdf.jsf?text $=\&$ docid $=225602 \&$ pageIndex $=0 \&$ doclang $=E N \&$ mode $=1$ st $\&$ dir $=\& o c c=-$ first\&part $=1 \&$ cid=11270533], accessed 20. June 2020

47 Lowther, J., Keeping Intra-EU ISDS Alive: The Supreme Court of Sweden Requests Preliminary Ruling from the CJEU on Validity of Arbitration Agreement in Light of Achmea Decision, Kluwer Arbitration 
started with Achmea is far from over, and pending cases at the CJEU will clarify the issue further.

\subsection{Extra-EU relations}

When it comes to agreements concluded between the European Union and third countries, the Commission seems to have a different position. Its approach is that these treaties do not undermine the autonomy of the legal system established by the Treaties. Under that background, it started to negotiate, on behalf of the EU, a convention establishing a multilateral court for the settlement of investment disputes. ${ }^{48}$

The Lisbon Treaty conferred an exclusive competence on the European Union in matters of foreign direct investment by making it part of the common commercial policy. ${ }^{49}$ Concerning other types of investments, the European Union has shared competence with the Member States. ${ }^{50}$ In fact, in its Opinion 2/15, which concerned the European Union's competence regarding the free trade agreement with Singapore, the CJEU explained that, there are two areas covered in the agreement in which the European Union does not have exclusive competence: the field of non-direct foreign investment and the investor-State dispute settlement regime. Those areas, therefore, fall within the shared competence of the European Union and the Member States. ${ }^{51}$

It should be noted that Opinion 2/15 relates only to the question whether the European Union has exclusive competence, and not to whether the content of the agreement is compatible with the EU law. It does not cover the issue of the jurisdiction of the CJEU in the settlement of disputes within the European Union relating to the interpretation of the EU law.

The European Commission is heading towards a multilateral investment court. Its idea is to create a permanent body that would settle investment disputes under

Blog, 5 March 2020, available at: [http://arbitrationblog.kluwerarbitration.com/2020/03/05/keepingintra-eu-isds-alive-the-supreme-court-of-sweden-requests-preliminary-ruling-from-the-cjeu-on-validity-of-arbitration-agreement-in-light-of-achmea-decision/?doing_wp_cron=1587814334.094820976 2573242187500], accessed 20. June 2020

48 Council of the European Union, Press release, Multilateral investment court: Council gives mandate to the Commission to open negotiations, 20 March 2018, available at: [https://www.consilium.europa.eu/en/ press/press-releases/2018/03/20/multilateral-investment-court-council-gives-mandate-to-the-commission-to-open-negotiations/], accessed 20. June 2020

49 Article 3(1)(e), articles 206 and 207 of TFEU

50 CJEU, Opinion 2/15 Free Trade Agreement with Singapore [2017] EU:C:2017:376, paragraph 243

51 Ibidem, disposition 
future and existing investment treaties. This multilateral court system would eventually replace the traditional arbitration framework..$^{52}$

It can be argued that the traditional arbitration framework could be perceived as "private justice" and, therefore, inappropriate for resolving issues involving the regulatory autonomy of states. Against this background, arbitrators are seen as lacking neutrality, lacking experience in public international and national law, and having vested interests. Concerning the structure of the arbitration framework, there is no form of appeal that could remedy errors of law or mistakes in fact finding, and the whole system is too expensive. ${ }^{53}$

It is evident that a multilateral reform is preferable to a bilateral approach. Meanwhile, the permanent court system concerns only trade and investment agreements concluded by the European Union, on the one hand, and the third country, on the other. It does not concern intra-EU bilateral investment treaties, and its aim is not replacing the ad hoc arbitral mechanism established by these treaties..$^{54}$ The immediate consequence of such approach is different treatment of investors established in the European Union and investors established in third countries. ${ }^{55}$

Investors established in the European Union can only rely on the system of investment protection provided by the EU law, i.e. protection that must be provided before national courts. From the practical standpoint, the investor will not be able to rely on a one-size-fits-all protection. Even though the EU law is applicable to all Member States, there are hurdles as the national court systems operate differently due to their distinctive procedural autonomy.

\subsection{The importance of CETA}

In 2015, Cecilia Malmström, Commissioner for Trade, announced: "CETA is an agreement with a major economic player. In economic terms, Canada is as big as Rus-

52 European Commission, President Jean-Claude Juncker, State of the Union Address: A Multilateral Investment Court, A new system for resolving disputes between foreign investors and states in a fair and efficient way, 13 September 2017, available at: [http://rade.ec.europa.eu/doclib/docs/2017/september/ tradoc_156042.pdf], accessed 20. June 2020

53 Brown, C.M., A Multilateral Mechanism for the Settlement of Investment Disputes. Some Preliminary Sketches, ICSID Review, vol. 32, Issue 3, 2017, pp. 673-690

54 Council of the European Union, Negotiating directives for a Convention establishing a multilateral court for the settlement of investment disputes, 12981/17, 1 March 2018, footnote 1, available at: [http:// data.consilium.europa.eu/doc/document/ST-12981-2017-ADD-1-DCL-1/en/pdf], accessed 20. June 2020

55 Advocate General Bot did not share that point of view. See Opinion of Advocate General Bot, Opinion 1/17, CETA EU-Canada [2019], EU:C:2019:72 (hereafter: Opinion of Advocate General), paragraph 185 and the following 
sia. It's bigger than Spain. It's bigger than Sweden, Belgium, Austria and the Czech Republic combined. It's therefore a vital part of the platform of agreements we are building to make sure the EU is properly connected to the global economy." 56

CETA was agreed in October 2016 after a long public debate. Its main goal is the trade liberalization between the EU and Canada by removing a vast majority of custom duties as well as other barriers to trade. Before its conclusion, the Commission consulted the relevant public, especially concerning the investor-state dispute settlement mechanism. ${ }^{57}$

CETA is not yet ratified by all Member States. Not only is the ratification process legally and politically difficult and time-consuming ${ }^{58}$, some Member States have not yet initiated $\mathrm{it}^{59}$ and some of them even announced that they would not ratify the agreement. ${ }^{60}$

Legally, however, as an international agreement concluded by the European Union, CETA is considered to be a legal act of EU institutions. ${ }^{61}$ CETA covers the exclusive and shared competence of the European Union. Even though it is not completely in force yet ${ }^{62}$, regarding the exclusive competence, CETA is binding for the institutions of the Union and its Member States and, therefore, its dispositions should prevail over provisions of secondary EU legislation. ${ }^{63}$ In this respect,

56 European Commission, Cecilia Malmström, Commissioner for Trade, Speech, CETA: Europe’s Next Trade Step, Workshop on the EU-Canada Comprehensive Economic and Trade Agreement (CETA), 9 Decembar 2015, available at: [http://trade.ec.europa.eu/doclib/docs/2015/december/tradoc_154022. pdf], accessed 20. June 2020

57 European Commission, Staff Working Document, Report, Online public consultation on investment protection and investor-to-state dispute settlement (ISDS) in the Transatlantic Trade and Investment Partnership Agreement (TTIP), available at: [http://trade.ec.europa.eu/doclib/docs/2015/january/tradoc_153044. pdf], accessed 20. June 2020

58 Gantz D. A. The CETA Ratification Saga: The Demise of ISDS in EU Trade Agreements?, Loyola University Chicago Law Journal, vol. 49, 2017, pp. 361 to 385

59 Laman L., Libre-échange: l'exécutif reporte la ratification du CETA, Mediapart, 21 Septembre 2018, available at: [https://www.mediapart.fr/journal/international/210918/libre-echange-l-executif-reporte-la-ratification-du-ceta], accessed 20. June 2020

60 Sisto A.; Jones G., Italy says it won't ratify EU-Canada trade deal; Canada plays down threat, Reuters, 13 July 2018, available at: [https://www.reuters.com/article/us-italy-canada-trade/italy-says-it-wontratify-eu-canada-trade-deal-canada-plays-down-threat-idUSKBN1K318Q], accessed 20. June 2020_

${ }_{61}$ Popescu R.-M., The jurisdiction of the Court Of Justice of the European Union to deliver a cancellation judgment regarding the international agreements to which the EU is party, LESIJ - Lex ET Scientia International Journal, Issue 1, 2016, pp. 92-100

${ }_{62}$ The trade related part of the agreement has provisionally entered into force on 21 September 2017. See Article 30.7 of the CETA

63 CJEU, C-344/04, IATA and ELFAA [2006] EU:C:2006:10, paragraph 35 
the Commission and the Council formulated a statement ${ }^{64}$ concerning the provisional application of certain CETA's dispositions.

Once in force, CETA will replace all extra-EU bilateral investment treaties concluded between the Member States and Canada. ${ }^{65}$

According to its case law, it is the CJEU who has the monopoly over the interpretation of acts adopted by the EU institutions as well as of the decisions adopted by the authority established by the international agreement. ${ }^{66}$ Therefore, with its entry into force, CETA will be completely integrated into the EU legal order, including the area of shared competence, and it will form part in the same way as other sources of the EU legislation. ${ }^{67}$ It is for this reason that the opinion of the CJEU concerning CETA's compatibility with the EU law is important.

CETA has two separate components, i.e. substantive and procedural rules. The latter pertains to investor-state dispute settlement mechanism. The investor-state dispute settlement mechanism enables disagreements to be settled where an investor considers that a Member State has infringed its obligations under the CETA. The investor has the opportunity to choose to bring a dispute against the Member State in which the investment was made before its courts or before the CETA Tribunal. In other words, the investor has the privilege of forum-shopping, i.e. to choose the jurisdiction which suits him better. ${ }^{68}$

CETA's principal goal is to promote cross-border investment between the European Union and Canada by affording a high level of protection to investors. This is done through substantive provisions. In order to achieve that goal, the Investment Court System plays the central part. In fact, the establishment of CETA's tribunals is the first step to implement the reform of the investor-state dispute settlement system developed by the Commission. ${ }^{69}$ Eventually, the CETA Investor-State Dispute Settlement mechanism would result in the establishment of the Investment Court System. At the occasion of the signing of CETA, the contracting parties

64 Council Decision (EU) 2017/38 of 28 October 2016 on the provisional application of the Comprehensive Economic and Trade Agreement (CETA) between Canada, of the one part, and the European Union and its Member States, of the other part, [2017] OJ L 11

65 Annex 30-A to the CETA

66 CJEU, C-192/89, Sevince [1990] EU:C:1990:322, paragraph 10

67 Opinion of Advocate General, paragraph 60

68 It seems that the CETA allows an investor to file a claim to before the CETA Tribunal after having unsuccessfully litigated before national courts. Article 8.10 of the CETA

69 European Commission, Concept paper, Investment in TTIP and beyond - the path for reform, Enhancing the right to regulate and moving from current ad hoc arbitration towards an Investment Court, available at: [http://trade.ec.europa.eu/doclib/docs/2015/may/tradoc_153408.PDF], accessed 20. June 2020 
established a joint interpretative instrument. ${ }^{70}$ It states that CETA moves decisively away from the traditional approach of investment dispute resolution and establishes independent, impartial and permanent investment Tribunals. ${ }^{71}$

The CETA investor-state dispute settlement mechanism is regulated by Chapter 8, Section F of the CETA, entitled "Resolution of investment disputes between investors and states". ${ }^{72}$ Section F provides for the establishment of two jurisdictions, the Tribunal and the Appellate Tribunal. It also contains the procedural framework for the settlement of disputes between an investor of one Party and the other Party, concerning the interpretation and application of the CETA. Notwithstanding its title, the mechanism also covers cases in which a Canadian investor submits a claim against the European Union.

It should be noted that the European Union supports the Commission's initiative of a global reform of the model for settling disputes between investors and States. The overall idea is to establish a permanent multilateral court. ${ }^{73}$ For now, the CETA is focused on two main aspects, i.e. the limitation of arbitration tribunals' broad interpretation of the agreement by explicitly referring to the right of the parties to regulate in the general interest, and the will to move towards a judicial system characterised, inter alia, by the independence and the impartiality of its members and the transparency of its procedures. ${ }^{74}$

Until now, the CJEU showed little compassion for extra-EU dispute settlement mechanisms. ${ }^{75}$ However, its opinion $1 / 17$ concerning the CETA shows that the CJEU is willing to accept such a mechanism. No doubt, this opinion will have a strong impact on the Commission's plans to establish a permanent multilateral court. The next chapters will explore how different the Investment Court System under CETA is in relation to intra- and extra-EU dispute settlement mechanisms scrutinized by the CJEU.

\footnotetext{
70 Joint Interpretative Instrument on the Comprehens ive Economic and Trade Agreement (CETA) between Canada and the European Union and its Member States [2017] OJ L 11

71 Ibidem, paragraph 6(f)

72 The relevant articles are Articles 8.18 to 8.45 of the CETA

73 Council of the European Union, Negotiating directives for a Convention establishing a multilateral court for the settlement of investment disputes, 12981/17 ADD 1 DLC 1, 1 March 2017, available at: [http:// data.consilium.europa.eu/doc/document/ST-12981-2017-ADD-1-DCL-1/en/pdf], accessed 20. June 2020

74 Opinion of Advocate General, paragraph 21

75 This will be explained later in the paper
} 


\section{AUTONOMY OF THE EU LAW}

\subsection{Autonomy of the EU legal order}

The autonomy of the EU law is the key element of the EU legal structure. It was first alluded to in Costa $v E_{n} e^{6}$, where the CJEU referred to "an independent source of law". From the very beginning, especially in its famous case Van Gend en $\operatorname{Loos}^{77}$, the CJEU established the autonomy of the EU law as a new legal order independent from any form of national or international recognition. ${ }^{78}$ This new legal order differs from any other treaty-based system within international law. The principal elements of that legal order are direct effect and primacy. According to the CJEU, it is by virtue of those elements that the EU law is distinguished from international law. The CJEU developed further the concept for both internal (case MOX-Plant ${ }^{79}$ ) and external relations (cases GATS ${ }^{80}$, Patent Court ${ }^{81}$ and $K_{a d i}{ }^{82}$ ). These cases are chosen because they show the negative stance of the CJEU towards any possibility of limiting its monopoly to provide a definitive interpretation of EU law.

Internally, those elements ensure that the EU law is applied uniformly and effectively across the European Union and enforced in Member States in different legal contexts. At a national level, national courts are responsible for the implementation of the EU law. A system of cooperation between the CJEU and national courts is established, according to which national courts are advised and sometimes obliged to ask the CJEU for the interpretation of the EU law. ${ }^{83}$ Through this system of autonomous interpretation of EU law, the CJEU protects its independence and monopoly to interpret EU law. Developed in that way, the concept of autonomy covers both procedural and substantive issues.

\footnotetext{
76 CJEU, C-6/64 Flaminio Costa v E.N.E.L. [1964] EU:C:1964:66

77 CJEU, C-26/62 Van Gend en Loos v Administratie der Belastingen [1963] EU:C:1963:1

78 There are two forms of recognition of the EU law; formal recognition, when the EU law is incorporated in national law, and practical recognition, when judges apply the EU law. Eckes C., International Rulings and the EU Legal Order: Autonomy as Legitimacy?, in Cremona M.; Thies A.; Wessel R. A. (editors), The European Union and International Dispute Settlement, Hart Publishing, Oxford and Portland, Oregon, 2017, p. 167

79 CJEU, C-459/03 Commission v Ireland [2006] EU:C:2006:345

80 CJEU, Opinion 1/94 Agreements annexed to the WTO Agreement [1994] EU:C:1994:384

81 CJEU, Opinion 1/09 Agreement creating a unified patent litigation system [2011] EU:C:2011:123

82 CJEU, Joined cases C-402/05 P and C-415/05 P Yassin Abdullah Kadi and Al Barakaat International Foundation $v$ Council of the European Union and Commission of the European Communities [2008] EU:C:2008:461

83 CJEU, Opinion 2/13 Accession of the EU to the ECHR [2014] EU:C:2014:2454, paragraph 176
} 
Externally, there is autonomy of the EU legislation from international and national laws. The CJEU has defined autonomy in such a way that the European Union may be a construction of international law; however, its internal legal order contains its own rules that replace the principles and mechanisms of international law. ${ }^{84}$ This autonomy is most relevant in the relationship and commitments of the European Union and its Member States. In case of conflicts between the EU internal rules and obligations resulting from international law, the EU law is given priority over conflicting international agreements and other international obligations. ${ }^{85}$

The dualist approach applied by the CJEU was severely criticized ${ }^{86}$ as there was no agreed directive as to how the autonomy of the EU law is supposed to operate at international level. Many international law scholars contest the absolute autonomy of the EU law as its ties with the international law is one of its highly specialized sub-systems ${ }^{87}$, while others do not consider it as international law at all. ${ }^{88}$

In the CJEU case law, external jurisdictions are often perceived as a possible menace to the EU legal order. When it comes to committing the EU to an international dispute settlement mechanism, the CJEU makes it clear that international agreements that would allow such a possibility are incompatible with the EU law. ${ }^{89}$ The reason for this is that these mechanisms could question its role as a final judge over matters that arise not only within the EU legal order (the relationship between EU institutions, between Member States and the European Union, between individuals and the European Union, and between individuals and Member States) but also between international law and the EU law.

84 Molnár T., The Concept of Autonomy of EU Law from the Comparative Perspective of International Law and the Legal Systems of Member States, Hungarian Yearbook of International Law and European Law, 2015 pp. $438-439$

85 In Kadi the CJEU stated that "an international agreement cannot affect the allocation of responsibilities defined in the Treaties, and consequently, the autonomy of the [EU] legal system". CJEU, Joined cases C-402/05 P and C-415/05 P Yassin Abdullah Kadi and Al Barakaat International Foundation v Council of the European Union and Commission of the European Communities [2008] EU:C:2008:461, paragraph 282

86 de Burca G., The European Court of Justice and the International Legal Order After Kadi, Harvard International Law Journal, Volume 51, Number 1/2010, pp. 1-49

87 Cremona M., de Witte B. (editors), EU Foreign Relations Law - Constitutional Fundamentals, Oxford, Hart Publishing, 2008

88 Weiler J. H. H., Haltern U. R., Autonomy of the Community Legal Order - Through the Looking Glass, Harvard International Law Journal, Volume 37, Number 2/1996, pp. 421-422

89 CJEU, Opinion 1/91 EEA Agreement - I [1991] EU:C:1991:490; Opinion 2/94 Accession by the Community to the ECHR [1996] EU:C:1996:140; Opinion 1/00 Agreement on the establishment of a European Common Aviation Area [2002] EU:C:2002:231, Opinion 2/13 Accession of the EU to the ECHR [2014] EU:C:2014:2454 
When it comes to mechanisms where the EU is not a contracting party, they are not a problem as long as the primacy of the EU law is respected. In that regard, questions concerning the EU law could be considered by external jurisdictions. It follows from the earlier case law, where the CJEU examined the possibility of enforcing an award issued by a commercial arbitration ${ }^{90}$, that the EU law could be discussed before and applied by external jurisdictions, as long as the CJEU has the last word over its interpretation and application. The possibility to use the EU law was conditioned by the need to ensure effective control of the application of the EU law by these external forums. This control depends on two things: could the external forum be considered a tribunal of a Member State in order to request a preliminary ruling on the interpretation of EU law; and if not, could the question of application of the EU law be raised at a later stage, e.g. when executing the arbitral award?'

As regards to investment arbitration tribunals, in Achmea the CJEU stated that they are not courts or tribunals of Members States and are thus not allowed to initiate preliminary ruling procedures. In that respect, Advocate General Wathelet expressed his position that an arbitral tribunal should be allowed to refer preliminary questions to the CJEU. ${ }^{92}$

Not only did the CJEU not follow that line of arguments, but it also went a step further in the Achmea case. The CJEU was not willing to allow political actors to submit the domestic legal order to the binding force of rulings awarded by external judicial bodies, even when the application of the EU law was not at stake. ${ }^{93}$

\subsection{Compatibility conditions established in the CJEU's case law}

The CJEU was called on several occasions to examine the compatibility of different international dispute settlement mechanisms with the EU law.

As a general rule, it maintains the view that these mechanisms are not incompatible with the EU legal system. It has stated that an international agreement providing

90 CJEU, C-126/97 Eco Swiss China Time Ltd v Benetton International NV [1999] EU:C:1999:269

91 Von Mehren R. B., The Eco-Swiss Case and International Arbitration, Arbitration International, vol. 19, Issue 4, 2003, pp. 465-470

92 Opinion of Advocate General Wathelet, C-567/14 Genentech Inc. v Hoechst GmbH, formerly Hoechst AG, Sanof-Aventis Deutschland GmbH [2016] EU:C:2016:177; opinion of Advocate General Wathelet, C-284/16 Slowakische Republik v Achmea BV, [2017] EU:C:2017:699

93 This conclusion is reached as a result of reasoning by analogy. Achmea did not deal with issues of EU law. Since EU law forms part of the Member States' domestic legal order, any investment disputes outside the EU judicial system would conflict with EU law, because potentially all cases might involve the interpretation or application of EU law. See also de Sadeleer N., The End of the Game: The Autonomy of the EU Legal Order Opposes Arbitral tribunals under Bilateral Investment Treaties Concluded between two Member States, European Journal of Risk Regulation, Vol. 10, no.1/2019, pp. 355-370 
for the establishment of a court responsible for the interpretation of its provisions and whose decisions are binding on the institutions, including the CJEU, is not in principle incompatible with the EU law. The competence of the EU in the field of international relations and its capacity to conclude international agreements necessarily entail the power to submit to the decisions of a court, which is created or designated by such agreements with regards to the interpretation and application of their provisions. ${ }^{94}$ However, in the end, each of them concluded that the particular mechanism in question could adversely affect the EU law autonomy.

In order for an international dispute settlement mechanism to be compatible with the EU law, the CJEU has established a number of conditions which should be met. ${ }^{95}$

Firstly, the protection of autonomy of the EU law must be provided, observance of which is ensured by the CJEU. It is important that the international agreement in question does not affect the allocation of powers fixed by the Treaties. According to Article 344 TFEU, the Member States undertake not to submit a dispute concerning the interpretation or application of the Treaties to any method of settlement other than those provided for in the Treaties. ${ }^{96}$

Secondly, the primacy of the EU law and its direct effect must be assured. Those characteristics of the EU law have given rise to a structured network of principles, rules and mutually interdependent legal relations binding the EU and its Member States reciprocally and its Member States to each other. ${ }^{97}$

Thirdly, the international agreement in question must not adversely affect the judicial system established by the Treaties, intended to ensure consistency and uniformity in the interpretation of the EU law. It cannot get around a system that is strongly marked by the quintessential role of the preliminary reference procedure. ${ }^{98}$

94 CJEU, Opinion 1/91 EEA Agreement — I [1991] EU:C:1991:490, paragraphs 40 and 70; opinion 1/09 Agreement creating a unified patent litigation system [2011] EU:C:2011:123, paragraphs 74 and 76; opinion 2/13 Accession of the EU to the ECHR [2014], EU:C:2014:2454, paragraphs 182 and 183; C-284/16, Slowakische Republikv Achmea BV [2018] EU:C:2018:158, paragraph 57

95 An international agreement may affect its own powers only if the indispensable conditions for safeguarding the essential character of those powers are satisfied and, consequently, there is no adverse effect on the autonomy of the EU legal order. CJEU, Opinion 2/13 Accession of the EU to the ECHR [2014] EU:C:2014:2454, paragraph 183

96 CJEU, Opinion 2/13 Accession of the EU to the ECHR [2014] EU:C:2014:2454, paragraph 201; C-284/16 Slowakische Republik v Achmea BV [2018] EU:C:2018:158, paragraph 32

${ }^{7}$ CJEU, Opinion 2/13 Accession of the EU to the ECHR [2014] EU:C:2014:2454, paragraphs 165 to 167 C-284/16 Slowakische Republik v Achmea BV [2018] EU:C:2018:158, paragraph 33

98 CJEU, Opinion 2/13 Accession of the EU to the ECHR [2014] EU:C:2014:2454, paragraph 174; C-284/16 Slowakische Republik v Achmea BV [2018] EU:C:2018:158, paragraph 35 
Fourthly, it must preserve the role of national courts and tribunals to ensure the full application of the EU law in all Member States and to ensure judicial protection of the rights of individuals under that law. ${ }^{99}$

Fifthly, to be compatible with the EU law, the international agreement must be compatible with the principles of mutual trust and sincere cooperation. ${ }^{100}$ The EU law is based on the fundamental premise that each Member State shares with all the other Member States, and recognises that they share with it, a set of common values on which the EU is founded. That premise implies and justifies the existence of mutual trust between the Member States that those values will be recognised, and therefore the law of the EU that implements them will be respected. It is precisely in that context that the Member States are obliged, by reason inter alia of the principle of sincere cooperation, to ensure in their respective territories the application of and respect for the EU law, and to take for those purposes any appropriate measure, whether general or particular, to ensure fulfilment of the obligations arising out of the Treaties or resulting from the acts of the institutions of the EU. ${ }^{101}$

Sixthly, the CJEU's exclusive jurisdiction to give binding interpretations of the EU law must be assured. This is done by assuring the preliminary ruling procedure, which is the keystone of the judicial system established by the Treaties. It sets up a dialogue between the CJEU and the courts and tribunals of the Member States, which secures uniform interpretation of the EU law, its consistency, its full effect, its autonomy, and the particular nature of the law established by the Treaties. ${ }^{102}$

Lastly, any action by the bodies that have been given decision-making powers by the international agreement must not have the effect of binding the EU and its institutions, in the exercise of their internal powers, to a particular interpretation

99 CJEU, Opinion 1/09 Agreement creating a unified patent litigation system [2011], EU:C:2011:123, paragraph 68; Opinion 2/13 Accession of the EU to the ECHR [2014], EU:C:2014:2454, paragraph 175; C-64/16 Associação Sindical dos Juizes Portugueses [2018] EU:C:2018:117, paragraph 33; C-284/16 Slowakische Republik v Achmea BV [2018] EU:C:2018:158, paragraph 36

100 Prechal A., Mutual Trust before the Court of Justice of the European Union, European Papers, Volume 2, Issue 1/2017, pp. 75 - 92; Van Elsuwege P., The duty of sincere cooperation (Art. 4(3) TEU) and its implications for the national interests of EU Member States in the field of external relations, UACES conference paper, Bilbao, 2015, p. 5, available at: [https://www.uaces.org/documents/papers/1501/ Van\%20Elsuwege.pdf], accessed 20. June 2020; Neframi E., The Duty of Loyalty: Rethinking its Scope through its Application in the Field of EU External Relations, Common Market Law Review, vol. 47, no. 2, 2010, pp. 323-359

101 CJEU, Opinion 2/13 Accession of the EU to the ECHR [2014] EU:C:2014:2454, paragraphs 168 and 173; C-284/16 Slowakische Republik v Achmea BV [2018] EU:C:2018:158, paragraph 34

102 CJEU, Opinion 2/13 Accession of the EU to the ECHR [2014] EU:C:2014:2454, paragraph 176; C-284/16 Slowakische Republikv Achmea BV [2018] EU:C:2018:158, paragraph 37 
of the rules of the EU law. ${ }^{103}$ On the contrary, the bodies in question cannot disregard the binding nature of decisions of the CJEU within the EU legal order or its binding case-law. ${ }^{104}$

Assessing the international dispute settlement mechanisms under scrutiny, the CJEU did not find the accession to the European Court of Human Rights, the Court of Justice of the European Free Trade Association States, the European Patent Court, and the investor-state under intra-EU bilateral investment treaties compatible with the autonomy of the EU legal system.

In the opinion of the Advocate General it was announced that the assessment of the investment court system under CETA will differ from other types of dispute settlement mechanisms. In fact, the Advocate General considered that Achmea, the main obstacle to recognition of external jurisdictions, is not applicable in the current case. He pointed out that the preservation of the autonomy of the EU legal order is not a synonym for autarchy and it requires merely that the integrity of that legal order is not undermined. ${ }^{105}$ The next chapter examines how the dispute settlement mechanism under CETA differs from other mechanisms that did not resist the CJEU's scrutiny.

\subsection{How different is the mechanism established by the CETA?}

\subsubsection{No interference with EU law}

The system of rules established by the CETA runs in parallel with the system of investment protection (substantive and procedural) established by EU law. ${ }^{106}$ Focusing on the judicial systems put in place in the Member States and in Canada, the CJEU observed that the dispute settlement mechanism under CETA stands outside those systems and that it cannot be considered to form part of the judicial system of either of the parties. ${ }^{107}$

If we compare the reasoning of the Advocate General and the CJEU in Achmea, the fact that the investment arbitration tribunal established by a bilateral investment treaty could not be considered a court or tribunal of a Member State was

\footnotetext{
103 CJEU, Opinion 2/13 Accession of the EU to the ECHR [2014] EU:C:2014:2454, paragraph 184; Opinion 1/00 Agreement on the establishment of a European Common Aviation Area [2002] EU:C:2002:231, paragraphs 12 and 13

104 CJEU, Opinion 1/92 EEA Agreement - II [1992] EU:C:1992:189, paragraphs 22 to 24

105 Opinion of the Advocate General, paragraph 59

106 Opinion of the Advocate General, paragraph 63

107 CJEU, Opinion 1/17, pp. 113 and 114
} 
negatively perceived. The argumentation there was focused on the fact that bodies that are not courts or tribunals of a Member State are not allowed to initiate preliminary ruling procedures. ${ }^{108}$ By creating a parallel judicial system the CJEU would lose its monopoly on the resolution of disputes in matters concerning the EU law and this is something that the CJEU was not willing to accept.

In Opinion 1/17, the fact that the dispute settlement mechanism is not part of the judicial system of a Member State does not present a problem, since it will never be called to interpret EU law. This aspect will be addressed further in the following chapters. However, it should be noted that in Achmea, the application of EU law was not at stake. It was only the possibility that such an arbitration tribunal could be called to apply EU law. ${ }^{109}$

The CJEU justified its position taken in Opinion $1 / 17$ by stressing the double aspect of international agreements. On the one hand, international agreements are an integral part of EU law and may therefore be the subject of references for a preliminary ruling. On the other hand, the jurisdiction of the CJEU and national courts to interpret and apply those agreements does not take precedence over either the jurisdiction of the courts and tribunals of the non-Member States with which those agreements were concluded or that of the international courts or tribunals that are established by such agreements.

The reciprocal nature of international agreements and the need to maintain the powers of the Union in international relations allow for the creation of an international forum with jurisdiction to interpret that agreement. ${ }^{10}$

\subsubsection{No direct effect}

The CETA has no direct effect. ${ }^{11}$ That means that it cannot be applied directly before domestic courts and authorities of the parties.

The direct effect is excluded deliberately and, according to the Advocate General, the main reason for that is to guarantee effective reciprocity between the parties. ${ }^{112}$ In this regard, he called on the CJEU's case law concerning the application

\footnotetext{
108 See Advocate General Wathelet, C284/16 Slowakische Republik v Achmea BV, [2017] EU:C:2017:699, paragraphs 90-131; CJEU, C-284/16 Slowakische Republikv Achmea BV [2018] EU:C:2018:158, paragraphs 44-49

109 See Advocate General Wathelet, C284/16 Slowakische Republikv Achmea BV, [2017] EU:C:2017:699, paragraph 228. In the Achmea judgement, the CJEU did not address this question

110 CJEU, Opinion 1/17, paragraphs 116-118

111 Article 30.6 of the CETA

112 Opinion of the Advocate General, paragraph 91
} 
of WTO agreements ${ }^{113}$, according to which the different positions regarding the direct/indirect application of these agreements would amount to a "lack of reciprocity", which would be capable of introducing an imbalance in the application of those agreements, since it would deprive European Union's legislative or executive bodies of the discretion which the equivalent bodies of the European Union's trading partners enjoy. ${ }^{114}$

Some commentators have addressed the question of reciprocity, stating that is not relevant in the context of the autonomy of the EU law, since it is a feature of an international dispute settlement mechanism and not an internal EU requirement. ${ }^{115}$ Also, the case law referred to by the Advocate General does not concern the compatibility of an extra-EU dispute settlement mechanism with EU law, but the direct effect of international agreements under the World Trade Organisation.

\subsubsection{Limited jurisdiction of the CETA Tribunal}

The CETA Tribunal has limited jurisdiction. In fact, its jurisdiction concerns the breach of an obligation under Section C (Non-discriminatory treatment) and Section D (Investment protection) of Chapter Eight of the CETA. The CETA Tribunal cannot decide cases that fall outside this scope. ${ }^{116}$

The Tribunal applies the relevant law, i.e. the CETA as interpreted in accordance with the Vienna Convention on the Law of Treaties, and other rules and principles of international law applicable between the Parties. ${ }^{117}$ It cannot apply the EU law or national law of the parties.

The investor can claim only damages resulting from a measure adopted by the Member State or the European Union. ${ }^{118} \mathrm{He}$ cannot ask for the determination of illegality of the measure in relation to the EU law or the national law of the Member States. He cannot contest it in the abstract or ask its annulation or to be

\footnotetext{
113 CJEU, joined cases C-659/13 and C-34/14 C \& J Clark International and Puma [2016] EU:C:2016:74, paragraph 94 to 98

114 Opinion of the Advocate General, paragraph 92

115 Gáspár-Szilágyi S., AG Bot in Opinion 1/17: The autonomy of the EU legal order v. the reasons why the CETA ICS might be needed, European Law Blog, 6 February 2018, available at: [http://europeanlawblog.eu/2019/02/06/ag-bot-in-opinion-1-17-the-autonomy-of-the-eu-legal-order-v-the-reasons-whythe-ceta-ics-might-be-needed/], accessed 20. June 2020. More on the issue see Semertzi A., The preclusion of direct effect in the recently concluded EU free trade agreements, Common Market Law Review, vol. 54, Issue 4, 2014, pp. 1125-1158

116 Article 8.18 of the CETA

117 Article 8.31.1 of the CETA

118 Articles 8.18.1 and 8.39 of the CETA
} 
brought in line with the CETA. ${ }^{119}$ There are only two possible types of awards, i.e. monetary damages and, under certain conditions, the restitution of property. ${ }^{120}$ The awards are only binding between the disputing parties and in respect of that particular case. ${ }^{121}$

The Advocate General found the question concerning the review of legality of acts crucial for the compatibility of the mechanism with the EU law. Though it recognised that the EU judicial system represents a complete set of legal remedies and procedures designed to ensure review of the legality of acts of the institutions ${ }^{122}$, he stated that the role of the CJEU in that respect is not called into question, since the CETA mechanism is intended solely to review the compatibility of the acts with the relevant provisions of the CETA, and not to review its legality in the light of EU law or the national law of Member States. ${ }^{123}$ He compared the CETA Tribunal's awards with the rulings and recommendations of the Dispute Settlement Body established under the World Trade Organisation. ${ }^{124}$

The CJEU took a similar approach, concluding that the power of interpretation and application conferred on the CETA Tribunal is confined to the provisions of the CETA. It compared the CETA mechanism with the unified patent litigation system, which did not pass the examination. The reason why the patent court did not pass was that it would be called upon to interpret and apply not only the provisions of the agreement establishing it, but also instruments of EU law, as well as to determine disputes pending before it in the light of the fundamental rights and general principles of EU law and to examine the validity of an act of the European Union. ${ }^{125}$

The CJEU also compared the CETA mechanism with the mechanism established by a bilateral investment agreement, as examined in Achmea. Apart from the fact that the arbitration tribunal established in the context of the latter mechanism could be called upon to give rulings on disputes that might concern the interpretation or application of EU law, the CJEU invoked the principle of mutual trust. That principle obliges each Member State to consider, other than in exceptional circumstances, that all the other Member States comply with EU law, including

\footnotetext{
119 Article 8.31.2 of the CETA

120 Article 8.39.1 of the CETA

121 Article 8.41.1 of the CETA

122 CJEU, Opinion 1/09 Agreement creating a unified patent litigation system [2011] EU:C:2011:123, paragraph 70

123 Opinion of the Advocate General, paragraph 124

124 Opinion of the Advocate General, paragraph 126

125 CJEU, Opinion 1/17, paragraphs 124-125
} 
fundamental rights, such as the right to an effective remedy before an independent tribunal. However, this principle is not applicable between the European Union and a non-Member State. ${ }^{126}$

\subsubsection{EU law "as a matter of fact"}

The CETA Tribunal may consider the EU law and the national law of Member States "as a matter of fact". ${ }^{127}$

In this context, there are several elements that have to be analysed. When deciding on an investor's claim against the host Member State or the Union, the CETA Tribunal will be called to determine the consistency of the State or Union's measure with the CETA. In this regard, it will consider domestic law of a Member State and EU law.

In order to consider domestic law of the parties, the CETA Tribunal will have to undertake an examination of the effect of the contested measure. That examination may require that domestic law of Member States, which includes EU law, be taken into account. Even though the CJEU puts it in different words, the CETA Tribunal may be called to apply EU law. However, it sees a way to bypass the obstacle; the examination of the effect of a measure consists of that party's domestic law being taken into account as a "matter of fact". ${ }^{128}$ In the CJEU's view, this is not equivalent to an interpretation. I will discuss this issue later in the paper.

Concerning the application of law of the parties, the CETA Tribunal has to follow the prevailing interpretation given to that law by courts or authorities of that party. ${ }^{129}$ Accordingly, when applying the EU law, it must follow the interpretation given by the CJEU.

The Advocate General put forward an interesting issue. He stated that it is essential that the CETA Tribunal be authorized to consider the domestic law of each party. By allowing the parties the possibility to rely on their national law that provides for the protection of public interest, the CETA strikes a balance between public and private interests of investors. In other words, when deciding the case the CETA Tribunal has to take into consideration the legitimate objectives in the public interest. ${ }^{130}$

\footnotetext{
126 CJEU, Opinion 1/17, paragraphs 127-129

127 Article 8.31.2 of the CETA

128 CJEU, Opinion 1/17, paragraph 131

129 Article 8.31.2 of the CETA

130 Opinion of the Advocate General, paragraph 130
} 
There is, however, one problem, and it concerns cases where the CJEU did not and does not have the opportunity to give its advice or provide guidance. In that case, the CETA Tribunal will be called to interpret the EU law in a way that is hardly conceivable with the requirement to apply it "as a matter of fact".

In fact, the CJEU decided that when a provision of the EU law, including secondary law, is open to more than one plausible interpretation, it requires, in principle, its own interpretation. ${ }^{131}$ The Advocate General proposed a way to overturn that problem. He outlined that the possible interpretation of the EU law given by the CETA Tribunal is made solely for the purposes of ruling on the dispute brought before it, and it is not binding on the authorities or the courts of the European Union. ${ }^{132} \mathrm{He}$ backed his argument stating that the Appellate Tribunal may modify or reverse the first-instance award on the basis of manifest errors in the appreciation of the facts, including that of the domestic law. ${ }^{133}$ This line of argument was accepted by the CJEU. ${ }^{134}$

These elements show that the margin of interpretation enjoyed by the CETA Tribunal and the Appellate Tribunal is very limited, which makes the mechanism compatible with the EU legal order. It should be noted that the provision to apply domestic law "as a matter of fact" is frequent in practice of international courts and tribunals that determine whether a state has complied with its international treaty obligations. ${ }^{135}$ Before delivering the Opinion 1/17, the real question was whether the CJEU would be willing to accept the blurred distinction between the interpretation of the EU law "as a matter of fact" and "as a matter of law", particularly, when it is provided by the CETA Tribunal. That issue has not been dealt with in its previous jurisprudence. ${ }^{136}$ Now, it is clear that the CJEU is willing to accept that possibility.

\footnotetext{
131 CJEU, Opinion 2/13 Accession of the EU to the ECHR [2014], EU:C:2014:2454, paragraph 245

132 Opinion of the Advocate General, paragraph 139

133 Opinion of the Advocate General, paragraph 148

134 CJEU; Opinion 1/17, paragraphs 131-133

135 Declève Q.; Isabelle Van Damme, Achmea: Potential Consequences for CETA, the Multilateral Investment Court, Brexit and other EU trade and investment agreements, International Litigation Blog, 13 March 2018, available at: [http://international-litigation-blog.com/achmea-consequences-ceta-mic-brexit/], accessed 20. June 2020

136 Ankersmit L., Judging International Dispute Settlement: From the Investment Court System to the Aarhus Convention's Compliance Committee, Amsterdam Law School Research Paper No. 2017-46, available at: [https://papers.ssrn.com/sol3/papers.cfm?abstract_id=3080988], accessed 20. June 2020
} 


\subsubsection{No effect on the division of powers between the $E U$ and its Member States}

To justify its opinion, the CJEU put forward a second reason: the CETA Tribunal has no jurisdiction to rule on disputes internal to the European Union. ${ }^{137}$ The European Union alone has the power to determine, when a Canadian investor seeks to challenge measures adopted by a Member State and/or by the Union, whether the dispute is to be brought against that Member State or against the Union. The exclusive jurisdiction of the CJEU to give rulings on the division of powers between the Union and its Member States is thereby preserved. ${ }^{138}$

The CETA does not affect the division of powers between the European Union and its Member States. It establishes an automatic procedure for determining the respondent party if the proceedings are initiated by a Canadian investor. ${ }^{139}$ Under that procedure, the European Union has the right to determine which Member State(s) will be the respondent(s). The rules for determining the respondent are contained in the Regulation No 912/214. ${ }^{140}$ It seems that the CJEU considers that its jurisdiction to apply the rules on the said division of powers in combination with the limited interpretation of the CETA Tribunal jurisdiction examination of the effect of that measure is enough to preserve its monopoly over the interpretation and the application of EU law.

\subsubsection{No preliminary ruling procedure}

There is no procedure for prior consultation of the CJEU, and the awards delivered by the CETA Tribunal would not systematically be subject to full review by the courts of the parties. The CJEU sees no problem with that solution. ${ }^{141}$

The Advocate General pointed out that the CETA contains sufficient guarantees to prevent that its mechanism of dispute resolution will not undermine the monopoly of the CJEU over the interpretation of the EU law. ${ }^{142}$ One of his ar-

\footnotetext{
137 In its opinions $1 / 09$ and 2/13, the CJEU maintained that the European Court of Human Rights and the European and Community Patents Court could be called to rule on the reciprocal relations between the European Union and its Member States, between the Member States themselves or between the investors of one Member State and the other Member States. For that reason, those courts were not compatible with the EU legal system

138 CJEU, Opinion 1/17, paragraph 132

139 Article 8.21 of the CETA

140 Regulation (EU) No 912/2014 of the European Parliament and of the Council of 23 July 2014 establishing a framework for managing financial responsibility linked to investor-to-state dispute settlement tribunals established by international agreements to which the European Union is party [2014] OJ L 257

141 CJEU, Opinion 1/17, paragraphs 134-135

142 Opinion of the Advocate General, paragraph 180
} 
guments in this regard is that the possibility to review the award before national courts is not ruled out, especially in the event of conflict with public policy. ${ }^{143}$ There are, however, situations in which the review would not be possible. ${ }^{144}$ The second one refers to the argument of reciprocity. If the CJEU had the possibility to intervene, the same possibility would be given to the highest court of the other party of the agreement. This would run counter to the purpose of the CETA's dispute settlement mechanism, i.e. to be neutral and independent from the domestic courts of the parties. ${ }^{145}$

It is not clear, however, why the prior consultation with the CJEU (or a national court) would not be possible, and why would affect the neutral position of the CETA Tribunal. The idea of that mechanism is to make sure that the CETA Tribunal gets clarification when it is not sure about the meaning of EU law (or other domestic law). Besides, such a mechanism is not a complete novelty. ${ }^{146}$

Some authors even suggested that the CJEU's open approach in opinions 1/91 and 1/00 demonstrates that external-EU tribunals could also refer preliminary questions, provided that the answers given by the CJEU were binding on the referring courts. ${ }^{147}$ However, there is a risk that allowing for such possibility of interpretation of one (or both) of the parties' courts would destroy the purpose of the proposed Investment Court System itself. ${ }^{148}$

\subsubsection{No effect on the operation of EU institutions}

The nature of the dispute settlement mechanism established by the CETA is different from the one already under scrutiny by the CJEU. The objective of the

143 Opinion of the Advocate General, paragraph 181

144 This is when the Convention on the Settlement of Investment Disputes between States and Nationals of Other States of the International Centre for Settlement of Investment Disputes (ICSID), signed in Washington on 18 March 1965, is applicable. See Opinion 1/17, footnote 145

145 Opinion of the Advocate General, paragraph 182

146 See Agreement on the withdrawal of the United Kingdom of Great Britain and Northern Ireland from the European Union and the European Atomic Energy Community [2020] OJ L 29; Pirker B., Dispute settlement and interpretation in the draft framework agreement between Switzerland and the EU, European Law Blog, 12 December 2018, available at: [http://europeanlawblog.eu/2018/12/12/ dispute-settlement-and-interpretation-in-the-draft-framework-agreement-between-switzerland-andthe-eu/], accessed 20. June 2020

147 Gáspár-Szilágyi S., A Standing Investment Court under TTIP from the Perspective of the Court of Justice of the European Union, The Journal of World Investment \& Trade, vol. 17, Issue 5, 2016

148 Pukan P., Implications of the CJEU Achmea decision for CETA's Investment Court System, International and European Law: International Trade and Investment Law 2017/2018, Master thesis, University of Amsterdam, 2018, p. 37, available at: [http://www.scriptiesonline.uba.uva.nl/document/667350], accessed 20. June 2020_ 
CETA is not to extend the rules of the EU law outside its borders, particularly to Canada. ${ }^{149}$ Although there is a substantive overlap with the investment protection provided by the EU law, the rules contained in the CETA are not identical. They form an independent body of law. ${ }^{150}$

The substantial rules on which a Canadian investor may rely on in disputes with a Member State or the Union are contained in Sections C and D of the Chapter Eight of the CETA. The most important of these are the principle of legality of investment, fair and equitable treatment, full security and protection, the most-favoured-nation clause, free transfer of payments, prohibition of direct and indirect expropriations etc.

In practice, the CETA Tribunal would be called to examine whether a measure adopted by a Member State or the EU on the basis of EU law breaches the CETA and the principles contained therein. To take an example, the concept of fair and equitable treatment does not have its direct equivalent in EU law, but its subject-matter falls within areas regulated by EU law. It includes principles of fair trial, non-discrimination, proportionality, transparency, absence of ambiguity and of unfair treatment, protection of legitimate expectations, protection against coercion and harassment, absence of denial of justice, etc. ${ }^{151}$ Since the CETA Tribunal will not decide on the basis of EU law, but will apply the CETA and the case law developed in the context of arbitration disputes, it is likely that the outcome of the weighing of interests will be different from what we could expect if only EU law would be applied. In case that the respondent Member State or the Union invokes public interests to justify a measure resulting in investment restriction, the CETA Tribunal will be called to examine the effects of primary and secondary EU law. It will provide findings of the same type as the CJEU is empowered to make that will result in definitive decisions that will bind the respondent Member State and the Union.

The concept of investment defined by the CETA is very broad permitting the CETA Tribunal to hear a wide range of disputes. The respondent Member State and the Union cannot circumvent jurisdiction of the CETA Tribunal to examine whether the disputed measure is in accordance with the CETA. ${ }^{152}$ That jurisdic-

\footnotetext{
149 That was one of the arguments stated by the CJEU in its opinions $1 / 91$ and $1 / 00$

150 Opinion of the Advocate General, paragraph 157

151 See Yannaca-Small K., 16. Fair and Equitable Treatment Standard, in Yannaca-Small K. (editor), Arbitration under International Investment Agreements: A Guide to the Key Issues, Oxford University Press, Oxford, 2010; Paulsson J., Denial of Justice in International Law, Cambridge University Press, Cambridge, 2005

152 Article 8.21.1 of the CETA
} 
tion covers all measures adopted by the Member State and/or the Union, which may relate to any form of act or practice, including measure of general application. If it finds that the contested measure breaches the CETA, the CETA Tribunal can order damages to be paid to the investor who logged the claim. The respondent Member State and/or the Union must recognise the award and comply with it by making the payment. ${ }^{153}$

The CJEU considers that the interpretation of EU law by the CETA Tribunal and the imposition of damages will not have any effect on the operation of the EU institutions. It compared the dispute settlement mechanism established by the CETA with the system in force within the World Trade Organisation and concluded that the possibility to award damages to private investors distinguishes the mechanism established by the CETA. ${ }^{154}$

I consider this aspect rather problematic. Although the CETA Tribunal cannot annul the contested measure, or oblige the Member States and/or the Union to harmonise its law to be compatible with the CETA, or impose a penalty on the respondent Member State and/or the Union, it can de facto call into question the level of protection of a public interest defined by national and EU law. In fact, the protection of public interest is the most likely line of argument that the respondent will put forward to justify the measure in question. The consequence of an award of damages could be the abandonment of interpretation of public interest defined by the CJEU in favour of the interpretation made by the CETA Tribunal. This is especially true if we consider the high amounts of damages awarded by arbitration tribunals in disputes between multinational companies and states.

The CJEU does not see this as a real threat. On the one hand, it considers the CETA as limiting the CETA Tribunal to determine whether the treatment of an investor or a covered investment is vitiated by a defect mentioned in Section C or $\mathrm{D}$ of Chapter Eight. ${ }^{155}$ On the other, the EU legislation is deemed to be both appropriate and necessary to achieve a legitimate objective of the Union and the $\mathrm{CJEU}$ is the sole responsible to ensure review of the compatibility of the level of protection of public interests established by EU law. ${ }^{156}$

The CJEU referred to the CETA and the Joint Interpretative Instrument according to which the provisions of Sections C and D of Chapter Eight cannot be interpreted in such a way as to prevent a Member State and/or the Union from

\footnotetext{
153 CJEU, Opinion 1/17, paragraphs 139-145

154 CJEU, Opinion 1/17, paragraph 146

155 CJEU, Opinion 1/17, paragraph 148

156 CJEU, Opinion 1/17, paragraph 151
} 
adopting and applying measures necessary to protect public interests and concluded that the CETA Tribunal has no jurisdiction to declare incompatible with the CETA the level of protection of a public interest established by the EU measures and, on that basis, to award damages. ${ }^{157}$ It cannot call into question the choices democratically made within a party relating to, inter alia, the level of protection of public order or public safety, the protection of public morals, the protection of health and life of humans and animals, the preservation of food safety, protection of plants and the environment, welfare at work, product safety, consumer protection or, equally, fundamental rights. ${ }^{158}$

I see a possible contradiction in the CJEU's reasoning. First, it pointed out the broad definitions of the notions of investments and measures given by the CETA, which allow to bring a claim against almost any measure, including laws of general application. Later, it relied on the limited jurisdiction of the CETA Tribunal and the fact that this jurisdiction cannot call into question choices made by the legislator on a number of legal bases. It remains to be seen how the CETA Tribunal will interpret the system of law established by the CETA and whether it will have the same approach in interpreting it as the CJEU.

\section{CONCLUSION}

The CJEU accepted the same line of argument as the Advocate General did. Criticism addressed to the Advocate General's opinion can be applied to the CJEU's opinion. For some commentators, it provides not much more than a summary of the talking points offered by the Council, the Commission and the vast majority of the 12 intervening Member States who were remarkably united in a bid to save the EU's new external trade and investment policy. ${ }^{159}$

In Achmea, the CJEU stressed the difference between bilateral investment agreements concluded by Member States and those concluded by the European Union. ${ }^{160}$ It could be argued that this difference was emphasised in order to leave open the possibility to declare an investor to state dispute settlement mechanism based on extra-EU/mixed agreements compatible with the EU legal order.

157 CJEU, Opinion 1/17, paragraph 152-154

158 CJEU, Opinion $1 / 17$, paragraph 160

159 Schepel H., A parallel universe: Advocate General Bot in Opinion 1/17, European law Blog, 7 February 2019, available at: [http://europeanlawblog.eu/2019/02/07/a-parallel-universe-advocate-general-bot-in-opinion-1-17/], accessed 20. June 2020.

160 CJEU, Case C-284/16 Slowakische Republik v Achmea BV [2018] EU:C:2018:158, paragraph 58 
It is evident that the compatibility of the CETA with EU law depends on the weight given to the concept of autonomy of the EU legal order. The CJEU's argumentation reduces it to its interpretative monopoly over EU law. ${ }^{161}$ It seems that the CETA Tribunal considers the EU law "as a matter of fact", that its decisions are not binding on national courts and the CJEU, and the guarantee to assure the application of the EU law as interpreted by the CJEU is enough to preserve the autonomy of the EU legal order.

However, it should be stated that there is a possibility for the CETA Tribunal to be called to interpret the EU law not only "as a matter of fact", i.e. when the content of the applicable law is disputed by the parties and there is no clear guidance by the CJEU. Although this may not be frequently as the "erroneous" application of the EU law could be remedied at the appellate phase, it still exists.

The problem is amplified in cases of enforcement of an award in which the CETA Tribunal de facto interprets the EU law. As it was mentioned before, there are situations when the award can avoid being reviewed on the ground of public policy. This situation can affect the uniform application of the EU law and, therefore, its autonomy.

Furthermore, since the investment protection is provided by the EU law, some dispositions of the CETA overlap with it and some contradict it. In fact, the CETA establishes a parallel system of investment protection that should not interfere with the investment protection established by the EU law. The question that arises in this regard is: does the autonomy of the EU law allow such a parallel system?

In Achmea, the CJEU found that the Member States could not remove from the jurisdiction of their own courts, and hence from the system of judicial remedies established by Article 19 of the Treaty on the European Union, disputes in fields covered by the EU law. ${ }^{162}$ Therefore, the CJEU did not limit the autonomy of the EU law to its interpretative monopoly.

In its Opinion 1/17, the CJEU has shown a different approach, i.e. the concept of autonomy allows the European Union to remove disputes in areas which are covered by the EU law from the judicial system established by the Treaties to an extra-EU jurisdiction, provided that these disputes do not concern the interpretation and application of the EU Law. Still, the important difference that remains

\footnotetext{
161 Schepel, op. cit., note 159

162 CJEU, Case C-284/16 Slowakische Republik v Achmea BV [2018] EU:C:2018:158, paragraph 55
} 
is that Achmea covers intra-EU disputes ${ }^{163}$, whereas CETA tribunal would be deciding disputes between a Member State and/or the EU and the third country. Submitting intra EU-disputes to arbitration shows distrust to national courts, and this cannot be allowed for the sake of mutual recognition.

By restricting the concept of autonomy of the EU legal order to procedural aspects, the CJEU allows the existence of two parallel investment protection systems, i.e. one regulated by EU law and the other by the CETA. Thus, it clearly shows that it does not want to take the challenge and become the competent legal institution for resolving conflicts between foreign investors and Member States and/or the European Union.

\section{REFERENCES}

\section{BOOKS AND ARTICLES}

1. Brown C. M., A Multilateral Mechanism for the Settlement of Investment Disputes. Some Preliminary Sketches, ICSID Review, vol 32, Issue 3, 2017, pp. 673-690

2. Collins R.; White N. D. (editors), International Organizations and the Idea of Autonomy: Institutional Independence in the International Legal Order, Routledge, London, 2011

3. Cremona M., de Witte B. (editors), EU Foreign Relations Law - Constitutional Fundamentals, Hart Publishing, Oxford, 2008

4. Cremona M.; Thies A.; Wessel R. A. (eds.), The European Union and International Dispute Settlement, Hart Publishing, Oxford and Portland, 2017

5. Chang H.J., Bad Samaritans: The Myth of Free Trade and the Secret History of Capitalism, Bloomsbury Press, New York, 2008

6. de Burca G., The European Court of Justice and the International Legal Order After Kadi, Harvard International Law Journal, vol. 51, no. 1, 2010, pp. 1-49

7. de Sadeleer N., The End of the Game: The Autonomy of the EU Legal Order Opposes Arbitral tribunals under Bilateral Investment Treaties Concluded between two Member States, European Journal of Risk Regulation, vol. 10, no.1, 2019, pp. 355-370

8. Gantz D. A. The CETA Ratification Saga: The Demise of ISDS in EU Trade Agreements?, Loyola University Chicago Law Journal, vol. 49, 2017, pp. 361-385

9. Gáspár-Szilágyi S., A Standing Investment Court under TTIP from the Perspective of the Court of Justice of the European Union, The Journal of World Investment \& Trade, vol. 17, Issue 5,2016

163 Some commentators believe that the issue of application of Achmea to extra-EU dispute remains unclear. See e.g. Gáspár-Szilágyi S., It Is not Just About Investor-State Arbitration: A Look at Case C-284/16, Achmea BV, European Papers, Vol. 3, No 1/2018, pp. 357-373, available at: [http://www. europeanpapers.eu/en/system/files/pdf_version/EP_EF_2018_I_020_Szilard_Gaspar_Szilagyi_0. pdf], accessed 20. June 2020 
10. Molnár T., The Concept of Autonomy of EU Law from the Comparative Perspective of International Law and the Legal Systems of Member States, Hungarian Yearbook of International Law and European Law, 2015

11. Neframi E., The Duty of Loyalty: Rethinking its Scope through its Application in the Field of EU External Relations, Common Market Law Review, vol. 47, no. 2, 2010, pp. 323-359

12. Semertzi A., The preclusion of direct effect in the recently concluded EU free trade agreements, Common Market Law Review, vol. 54, Issue 4, 2014, pp. 1125-1158

13. Paulsson J., Denial of Justice in International Law, Cambridge University Press, Cambridge, 2005

14. Popescu R.-M., The jurisdiction of the Court Of Justice of the European Union to deliver a cancellation judgment regarding the international agreements to which the EU is party, LESIJ - Lex ET Scientia International Journal, Issue 1, 2016, pp. 92-100

15. Prechal A., Mutual Trust before the Court of Justice of the European Union, European Papers, vol. 2, Issue 1, 2017, pp. 75 - 92

16. Von Mehren R. B., The Eco-Swiss Case and International Arbitration, Arbitration International vol. 19, Issue 4, 2003, pp. 465-470

17. Weiler J. H. H., Haltern U. R., Autonomy of the Community Legal Order - Through the Looking Glass, Harvard International Law Journal, vol. 37, no. 2, 1996, pp. 421-422

18. Williamson J., Curbing the Boom-Bust Cycle: Stabilizing Capital Flows to Emerging Markets: Policy Analyses in International Economics, Institute of International Economics, Washington, 2005

19. Yannaca-Small K. (ed.), Arbitration under International Investment Agreements: A Guide to the Key Issues, Oxford University Press, Oxford, 2010

\section{EU LAW}

1. Comprehensive Economic and Trade Agreement (CETA) of 30 October 2016 between the European Union and its Member States, of the one part, and Canada, of the other part, [2017] OJ L 11

2. Council and Commission Decision of 23 September 1997 on the conclusion, by the European Communities, of the Energy Charter Treaty and the Energy Charter Protocol on energy efficiency and related environmental aspects (98/181/EC, ECSC, Euratom) [1998] OJ L 69

3. Council Decision (EU) $2017 / 38$ of 28 October 2016 on the provisional application of the Comprehensive Economic and Trade Agreement (CETA) between Canada, of the one part, and the European Union and its Member States, of the other part, [2017] OJ L 11

4. Joint Interpretative Instrument on the Comprehensive Economic and Trade Agreement (CETA) between Canada and the European Union and its Member States [2017] OJ L 11

5. Regulation (EU) No 1219/2012 of the European Parliament and of the Council of 12 December 2012 establishing transitional arrangements for bilateral investment agreements between Member States and third countries [2012] OJ L 351

6. Regulation (EU) No 912/2014 of the European Parliament and of the Council of 23 July 2014 establishing a framework for managing financial responsibility linked to inves- 
tor-to-state dispute settlement tribunals established by international agreements to which the European Union is party [2014] OJ L 257

7. Treaty on the Functioning of the European Union, Consolidated version [2012] OJ C $326 / 47$

\section{COURT OF JUSTICE OF THE EUROPEAN UNION}

1. C-126/97 Eco Swiss China Time Ltd v Benetton International NV [1999] EU:C:1999:269

2. C-192/89, Sevince [1990] EU:C:1990:322

3. C-26/62 Van Gend en Loos v Administratie der Belastingen [1963] EU:C:1963:1

4. C-459/03 Commission v Ireland [2006] EU:C:2006:345

5. C-6/64 Flaminio Costa v E.N.E.L. [1964] EU:C:1964:66

6. C-64/16 Associação Sindical dos Juizes Portugueses [2018] EU:C:2018:117

7. Case C-284/16 Slowakische Republik v Achmea BV [2018] EU:C:2018:158

8. Case C-344/04, IATA and ELFAA [2006] EU:C:2006:10

9. Cases T-624/15, T-694/15 and T-704/15, European Food SA and Others $v$ European Commission [2019] EU:T:2019:423

10. Joined cases C-402/05 P and C-415/05 P Yassin Abdullah Kadi and Al Barakaat International Foundation $v$ Council of the European Union and Commission of the European Communities [2008] EU:C:2008:461

11. Joined cases C-659/13 and C-34/14 C \& J Clark International and Puma [2016] EU:C:2016:74

12. Opinion 1/00 Agreement on the establishment of a European Common Aviation Area [2002] EU:C:2002:231

13. Opinion 1/09 Agreement creating a unified patent litigation system [2011] EU:C:2011:123

14. Opinion 1/17 EU-Canada CET Agreement [2019] EU:C:2019:341

15. Opinion 1/91 EEA Agreement — I [1991] EU:C:1991:490

16. Opinion 1/92 EEA Agreement — II [1992] EU:C:1992:189

17. Opinion 1/94 Agreements annexed to the WTO Agreement [1994] EU:C:1994:384

18. Opinion 2/13 Accession of the EU to the ECHR [2014] EU:C:2014:2454

19. Opinion 2/94 Accession by the Community to the ECHR [1996] EU:C:1996:140

20. Opinion of Advocate General Bot, Opinion 1/17 CETA EU-Canada [2019], EU:C:2019:72

21. Opinion of Advocate General Wathelet, C-284/16 Slowakische Republikv Achmea BV [2017] EU:C:2017:699

22. Opinion of Advocate General Wathelet, C-567/14 Genentech Inc. v Hoechst GmbH, formerly Hoechst AG, Sanofi-Aventis Deutschland GmbH [2016] EU:C:2016:177

\section{CASE LAW OF ARBITRATION TRIBUNALS}

1. ICSID Case No ARB/05/20, Ioan Micula, Viorel Micula, SC European Food SA, SC Starmill SRI, SC Multipack SRL v Romania, Final Award of 11 December 2013 
2. ICSID Case No.ARB/13/36, Eiser Infrastructure Limited and Energia Solar Luxembourg Sarl v. Kingdom of Spain

3. ICSID, Case No. ARB/05/20 Annulment Proceedings, Ioan Micula, Viorel Micula and others (Respondents on Annulment) (Claimants) v. Romania (Applicant on Annulment) (Respondent), Decision on Annulment of 26 February 2016

4. ICSID, Case No. ARB/12/12, Vattenfall AB and others $v$ Federal Republic of Germany

5. ICSID, Case No. ARB/13/31, Antin Infrastructure Services Luxembourg Sàrl and Antin Energia Termosolar BV v Kingdom of Spain

6. ICSID, Case No. ARB/14/1, Masdar Solar \& Wind Cooperatief U.A. v. Kingdom of Spain

7. ICSID, Case No. ARB/14/3, Blusun S.A., Jean-Pierre Lecorcier and Michael Stein v. Italian Republic

8. SCC, Case No. 063/2015, Novenergia v. Kingdom of Spain

9. SCC, Case No. V 062/2012, Charanne B.V. and Construction Investments S.á.r.l v. Kingdom of Spain

10. SCC, Case No. V 2013/153, Isolux Netherlands, BV v. Kingdom of Spain

11. SCC, Case No. V 2014/163, PL Holdings S.à.r.l. v. Republic of Poland, Partial award of 28 June 2017

\section{OTHER DECISIONS}

1. Commission Decision (EU) 2015/1470 of 30 March 2015 on State aid SA.38517 (2014/C) (ex 2014/NN) implemented by Romania - Arbitral award Micula v Romania of 11 December 2013 (notified under document C(2015) 2112), [2015] OJ L 232

2. Cour d'appel Bruxelles, Arrêt du 12 mars 2019, 2016/AR/393 joint avec 2016/AR/394, available at: [https://jusmundi.com/en/document/decision/fr-ioan-micula-viorel-miculaand-others-v-romania-i-arret-de-la-cour-dappel-de-bruxelles-tuesday-12th-march-2019]

3. Supreme Court of the United Kingdom, Judgement of 19 February 2020, Micula and others (Respondents/Cross-Appellants) v Romania (Appellant/Cross-Respondent), UKSC 2018/0177, [2020] UKSC 5, available at: [https://www.supremecourt.uk/cases/docs/uksc2018-0177-judgment.pdf]

4. Svea Court of Appeal, Judgement of 22 February 2019, T 8538-17, T 12033-17, unofficial translation, available at: [https:/www.italaw.com/sites/default/files/case-documents/ italaw10447.pdf]

5. Högsta Domstolen, Republiken Polen v. PL Holdings S.Á.R.L., Begäran om förhandsavgörande den 12 december 2020, T 1569- 19, available at: [https:/www.italaw.com/sites/ default/files/case-documents/italaw11099.pdf]

6. Högsta Domstolen, Republic of Poland v. PL Holdings S.Á.R.L., Request for a preliminary ruling of 27 February 2020, C-109/20, translation in English, available at: [http:// curia.europa.eu/juris/showPdf.jsf?text=\&docid=225602\&pageIndex $=0 \&$ doclang=en $\&$ mode $=$ req $\&$ dir $=\&$ occ $=$ first $\&$ part $=1 \&$ cid $=630531]$ 


\section{WEBSITES REFERENCES}

1. Agreement for the termination of bilateral investment treaties between the Member States of the European Union, available at: [https://ec.europa.eu/info/sites/info/files/business_economy_euro/banking_and_finance/documents/200505-bilateral-investment-treaties-agreement_en.pdf], accessed 20. June 2020

2. Ankersmit L., Judging International Dispute Settlement: From the Investment Court System to the Aarhus Convention's Compliance Committee, Amsterdam Law School Research Paper No. 2017-46, available at: [https://papers.ssrn.com/sol3/papers.cfm?abstract_id=3080988], accessed 20. June 2020

3. Cimmino J. et al., A Global Strategy for Shaping the Post-COVID-19 World, The Atlantic Council of the United States, 2020, available at: [https://www.atlanticcouncil.org/wp-content/uploads/2020/07/AC-A-Global-Strategy-for-Shaping-the-Post-COVID-19-World. pdf], accessed 20. June 2020

4. Council of the European Union, Negotiating directives for a Convention establishing a multilateral court for the settlement of investment disputes, 12981/17, 1 March 2018, footnote 1, available at: [http://data.consilium.europa.eu/doc/document/ST-12981-2017-ADD-1DCL-1/en/pdf], accessed 20. June 2020

5. Council of the European Union, Press release, Multilateral investment court: Council gives mandate to the Commission to open negotiations, 20 March 2018, available at: [https://www.consilium.europa.eu/en/press/press-releases/2018/03/20/multilateral-investment-court-council-gives-mandate-to-the-commission-to-open-negotiations/], accessed 20. June 2020

6. Court of Justice of the European Union, InfoCuria, Case C-638/19 P, appeal brought on 27 August 2019 by European Commission against the judgment of the General Court (Second Chamber, Extended Composition) delivered on 18 June 2019 in Case T-624/15: European Food e.a. $v$ Commission, available at: [http://curia.europa.eu/juris/document/ document.jsf?text $=\&$ docid $=219134 \&$ pageIndex $=0 \&$ doclang $=E N \&$ mode $=$ req \&dir $=$ \&oc $\mathrm{c}=$ first\&part $=1 \& \mathrm{cid}=6657449]$, accessed 20. June 2020

7. Croisant G., Micula Case: The UK Supreme Court Rules That The EU Duty Of Sincere Co-operation Does Not Affect The UK's International Obligations Under The ICSID Convention, Kluwer Arbitration Blog, 20 February 2020, available at: [http://arbitrationblog.kluwerarbitration.com/2020/02/20/micula-case-the-uk-supreme-court-rules-that-the-eu-dutyof-sincere-co-operation-does-not-affect-the-uks-international-obligations-under-the-icsid-convention/], accessed 20. June 2020

8. Dahlquist J., Spain challenges Novenergia arbitral award in Swedish court, relying on the Achmea judgment, 23 May 2018, available at: [https://aquiescencia.net/2018/05/23/spain-challenges-novenergia-arbitral-award-in-swedish-court-relying-on-the-achmea-judgment/], accessed 20. June 2020

9. Declaration of the Representative of the Governments of Hungary of 16 January 2019 on the legal consequences of the Judgment of the Court of Justice in Achmea and on Investment Protection in the European Union, available at: [http://www.kormany.hu/download/5/1b/81000/Hungarys $\% 20$ Declaration $\% 20$ on\%20Achmea.pdf], accessed 20. June 2020

10. Declaration of the Representatives of the Governments of the Member States of 15 January 2019 on the legal consequences of the Judgment of the Court of Justice in Achmea and on 
Investment Protection in the European Union, available at: [https:/ec.europa.eu/info/sites/ info/files/business_economy_euro/banking_and_finance/documents/190117-bilateral-investment-treaties_en.pdf], accessed 20. June 2020

11. Declaration of the Representatives of the Governments of the Member States of 16 January 2019 on enforcement of the Judgment of the Court of Justice in Achmea and on Investment Protection in the European Union, available at: [https:/www.regeringen.se/48ee19/contentassets/d759689c0c804a9ea7af6b2de7320128/achmea-declaration.pdf], accessed 20. June 2020

12. Declève Q.; Isabelle Van Damme, Achmea: Potential Consequences for CETA, the Multilateral Investment Court, Brexit and other EU trade and investment agreements, International Litigation Blog, 13 March 2018, available at: [http://international-litigation-blog.com/achmea-consequences-ceta-mic-brexit/], accessed 20. June 2020

13. Energy Charter Secretariat, Italy, available at: [https://energycharter.org/who-we-are/members-observers/countries/italy/], accessed 20. June 2020

14. European Commission, Cecilia Malmström, Commissioner for Trade, Europe's Next Trade Step, Workshop on the EU-Canada Comprehensive Economic and Trade Agreement (CETA), 9 Decembar 2015, available at: [http://trade.ec.europa.eu/doclib/docs/2015/december/tradoc_154022.pdf], accessed 20. June 2020

15. European Commission, Communication to the European Parliament, the Council, the European Economic and Social Committee and the Committee of the Regions, Towards a comprehensive European international investment policy, COM/2010/0343 final, available at: [https://eurlex.europa.eu/LexUriServ/LexUriServ.do?uri=COM:2010:0343:FIN:EN:PDF], accessed 20. June 2020

16. European Commission, Concept paper, Investment in TTIP and beyond - the path for reform, Enhancing the right to regulate and moving from current ad hoc arbitration towards an Investment Court, available at: [http://trade.ec.europa.eu/doclib/docs/2015/may/tradoc_153408. PDF], accessed 20. June 2020

17. European Commission, Fact Sheet: Commission provides guidance on protection of cross-border EU investments - Questions and Answers, 19 July 2018, available at: [http://europa.eu/rapid/ press-release_MEMO-18-4529_en.htm], accessed 20. June 2020

18. European Commission, Negotiations and agreements, available at: [https://ec.europa.eu/ trade/policy/countries-and-regions/negotiations-and-agreements], accessed 20. June 2020

19. European Commission, President Jean-Claude Juncker, State of the Union Address: A Multilateral Investment Court, $A$ new system for resolving disputes between foreign investors and states in a fair and efficient way, 13 September 2017, available at: [http://trade.ec.europa.eu/ doclib/docs/2017/september/tradoc_156042.pdf], accessed 20. June 2020

20. European Commission, Press release, Capital Markets Union: Commission provides guidance on protection of cross-border EU investments, 19 July 2018, available at: [http://europa.eu/ rapid/press-release_IP-18-4528_en.htm?locale=en], accessed 20. June 2020

21. European Commission, Press release, State aid: Commission refers Romania to Court for failure to recover illegal aid worth up to $€ 92$ million, 7 December 2018, available at: [http://europa. eu/rapid/press-release_IP-18-6723_en.htm], accessed 20. June 2020 
22. European Commission, Staff Working Document, Report, Online public consultation on investment protection and investor-to-state dispute settlement (ISDS) in the Transatlantic Trade and Investment Partnership Agreement (TTIP), available at: [http://trade.ec.europa.eu/doclib/ docs/2015/january/tradoc_153044.pdf], accessed 20. June 2020

23. Gáspár-Szilágyi S., AG Bot in Opinion 1/17: The autonomy of the EU legal order v. the reasons why the CETA ICS might be needed, European Law Blog, 6 February 2018, available at: [http://europeanlawblog.eu/2019/02/06/ag-bot-in-opinion-1-17-the-autonomy-of-the-eulegal-order-v-the-reasons-why-the-ceta-ics-might-be-needed/], accessed 20. June 2020

24. Gáspár-Szilágyi S., It Is not Just About Investor-State Arbitration: A Look at Case C-284/16, Achmea BV, European Papers, Vol. 3, No 1/2018, pp. 357-373, available at: [http://www. europeanpapers.eu/en/system/files/pdf_version/EP_EF_2018_I_020_Szilard_Gaspar_Szilagyi_0.pdf], accessed 20. June 2020

25. International Monetary Fund, available at: [http://data.imf.org/], accessed 20. June 2020

26. International Monetary Fund, Press Release No. 10/510, IMF Publishes First Worldwide Survey of Foreign Direct Investment Positions, 22.12.2010, available at: [https://www.imf.org/en/ News/Articles/2015/09/14/01/49/pr10510], accessed 20. June 2020

27. Laman L., Libre-échange: l'exécutif reporte la ratification du CETA, Mediapart, 21 Septembre 2018, available at: [https://www.mediapart.fr/journal/international/210918/libre-echange-1-executif-reporte-la-ratification-du-ceta], accessed 20. June 2020

28. Loungani P.; Razin A., How Beneficial Is Foreign Direct Investment for Developing Countries?, Finance \& Development, Volume 38, Number 2, 2001, available at: [https://www.imf.org/ external/pubs/ft/fandd/2001/06/loungani.htm], accessed 20. June 2020

29. Lowther J., Keeping Intra-EU ISDS Alive: The Supreme Court of Sweden Requests Preliminary Ruling from the CJEU on Validity of Arbitration Agreement in Light of Achmea Decision, Kluwer Arbitration Blog, 5 March 2020, available at: [http://arbitrationblog.kluwerarbitration. com/2020/03/05/keeping-intra-eu-isds-alive-the-supreme-court-of-sweden-requests-preliminary-ruling-from-the-cjeu-on-validity-of-arbitration-agreement-in-light-of-achmea-decision/?doing_wp_cron=1587814334.0948209762573242187500], accessed 20. June 2020

30. Materljan I., Investment Protection and the EU Law, International Commercial Arbitration Review (Вестник международного коммерческого арбитража), Vol. 17, No. 2/2018., pp. 114-143, available at: [http://arbitrationreview.ru/wp-content/uploads/2019/04/!vestnik_MKA_cover_2_2018.pdf], accessed 20. June 2020

31. Organisation for Economic Co-operation and Development, FDI flows, available at: [https://data.oecd.org/fdi/fdi-flows.htm], accessed 20. June 2020

32. Organization for Economic Cooperation and Development, Business and Finance Outlook 2016, Chapter 8: The impact of investment treaties on companies, shareholders and creditors, available at: [https://www.oecd.org/daf/inv/investment-policy/BFO-2016-Ch8-Investment-Treaties.pdf], accessed 20. June 2020

33. Organization for Economic Cooperation and Development, Foreign Direct Investment Statistics: Data, Analysis and Forecasts, available at: [http://www.oecd.org/investment/statistics. htm], accessed 20. June 2020 
34. Pirker B., Dispute settlement and interpretation in the draft framework agreement between Switzerland and the EU, European Law Blog, 12 December 2018, available at: [http://europeanlawblog.eu/2018/12/12/dispute-settlement-and-interpretation-in-the-draft-frameworkagreement-between-switzerland-and-the-eu/], accessed 20. June 2020

35. Pukan P., Implications of the CJEU Achmea decision for CETA's Investment Court System, International and European Law: International Trade and Investment Law 2017/2018, Master thesis, University of Amsterdam, 2018, available at: [http://www.scriptiesonline.uba.uva.nl/ document/667350], accessed 20. June 2020

36. Schepel H., A parallel universe: Advocate General Bot in Opinion 1/17, European law Blog, 7 February 2019, available at: [http://europeanlawblog.eu/2019/02/07/a-parallel-universe-advocate-general-bot-in-opinion-1-17/], accessed 20. June 2020

37. Sisto A.; Jones G., Italy says it won't ratify EU-Canada trade deal; Canada plays down threat, Reuters, 13 July 2018, available at: [https://www.reuters.com/article/us-italy-canada-trade/italy-says-it-wont-ratify-eu-canada-trade-deal-canada-plays-down-threat-idUSKBN1K318Q], accessed 20. June 2020

38. United Nations Conference on Trade and Development, Global Investment Trends Monitor (Series), available at: [https://unctad.org/en/Pages/Publications/Global-Investment-Trends-Monitor-\%28Series\%29.aspx], accessed 20. June 2020

39. United Nations Conference on Trade and Development, World Investment Report 2003, FDI Policies for Development: National and International Perspectives, United Nations, New York, and Geneva, 2003, available at: [https://unctad.org/en/docs/wir2003light_en.pdf], accessed 20. June 2020

40. United Nations Conferences on Trade and Development, The IPA Observer: Investment Promotion agencies striving to overcome the COVID-19 challenge, Special issue 8, April 2020, available at: [https://unctad.org/en/PublicationsLibrary/diaepcbinf2020d2_en.pdf?user=46], accessed 20. June 2020

41. Van Elsuwege P., The duty of sincere cooperation (Art. 4(3) TEU) and its implications for the national interests of EU Member States in the field of external relations, UACES conference paper, Bilbao, 2015, p. 5, available at: [https://www.uaces.org/documents/papers/1501/Van\%20 Elsuwege.pdf], accessed 20. June 2020 